Published in final edited form as:

Int Rev Neurobiol. 2018 ; 141: 211-250. doi:10.1016/bs.irn.2018.07.027.

\title{
Molecular Imaging of the Cholinergic system in Parkinson's disease
}

\author{
Nicolaas I. Bohnen, MD, PhD ${ }^{1,2,3,4,{ }^{\star}, \text { Prabesh Kanel, PhD }}{ }^{1,4}$, and Martijn L.T.M. Müller, \\ $\mathrm{PhD}^{1,4}$ \\ ${ }^{1}$ Department of Radiology, University of Michigan, Ann Arbor, MI, USA \\ ${ }^{2}$ Department of Neurology, University of Michigan, Ann Arbor, MI, USA \\ ${ }^{3}$ Veterans Administration Ann Arbor Healthcare System, Ann Arbor, MI, USA \\ ${ }^{4}$ Morris K. Udall Center of Excellence for Parkinson's Disease Research, University of Michigan, \\ Ann Arbor, MI, United States
}

\begin{abstract}
One of the first identified neurotransmitter in the brain, acetylcholine is an important modulator that drives changes in neuronal and glial activity. For more than two decades, the main focus of molecular imaging of the cholinergic system in Parkinson's disease (PD) has been on cognitive changes. Studies have shown that degeneration of the cholinergic system is a major determinant of dementia in PD. Within the last decade, the focus is expanding to studying cholinergic correlates of mobility impairments, dyskinesias, olfaction, sleep, visual hallucinations and risk taking behavior in this disorder. These studies increasingly recognize that the regional topography of cholinergic brain areas associates with specific functions. In parallel with this trend, more recent molecular cholinergic imaging approaches are investigating cholinergic modulatory functions and contributions to large-scale brain network functions. A novel area of research is imaging cholinergic innervation functions of peripheral autonomic organs that may have the potential of future prodromal diagnosis of PD. Finally, emerging evidence of hypercholinergic activity in prodromal and symptomatic LRRK2 PD may reflect neuronal cholinergic compensation versus a response to neuro-inflammation. Molecular imaging of the cholinergic system has led to many new insights in the etiology of many dopamine non-responsive symptoms of PD and is poised to guide and evaluate future cholinergic drug development in PD.
\end{abstract}

\section{Keywords}

Acetylcholine; Alzheimer disease; brain network; cognition; dementia with Lewy bodies; gait; motor; Parkinson disease

\footnotetext{
*Corresponding author email address: nbohnen@umich.edu. Disclaimer: The authors report no relevant disclosures.

Competing interests: The authors report no competing interests.
} 


\section{INTRODUCTION}

Although Parkinson's disease (PD) is most well known for its motor manifestations, dementia is a very common occurrence in advancing PD (Halliday, Hely, Reid, \& Morris, 2008; Williams-Gray et al., 2013). Early cholinergic molecular imaging studies in PD were aimed at investigating cognitive changes in this disorder. These studies were likely inspired by the cholinergic hypothesis of dementia, which was the prevailing dementia theory at that time and had its roots in observations of prominent cholinergic basal forebrain (CBFB) loss in postmortem brains of patients with Alzheimer's disease (AD) (Davies \& Maloney, 1976; Perry, Perry, Blessed, \& Tomlinson, 1977). The primary assumption of this hypothesis was that loss of cholinergic neurons in the brain results in impaired cholinergic neurotransmission and declining memory function (Bartus, Dean, Beer, \& Lippa, 1982; Drachman \& Leavitt, 1974). Interestingly, around the same time, studies reported on CBFB losses in patients with PD and related dementias that were comparable or even exceeded losses observed in AD (Arendt, Bigl, Arendt, \& Tennstedt, 1983; Whitehouse, Hedreen, White, \& Price, 1983). The cholinergic hypothesis of dementia provided a conceptual framework that led to the successful approval of cholinesterase inhibitors for AD and later PD with dementia (PDD). Subsequently, the popularity of the cholinergic hypothesis of dementia declined, especially in AD. This may have several reasons. First, benefits of cholinesterase inhibitors in clinical practice were modest at best (Zemek et al., 2014). Second, in vivo molecular imaging studies in the early 1990s showed cholinergic losses in AD that were only prominent in end-stage disease (N. I. Bohnen et al., 2003; Iyo et al., 1997; D.E. Kuhl et al., 1999; D. Kuhl et al., 1996). A post-mortem study in the late 1990s confirmed these in vivo observations, showing that loss of forebrain cholinergic neurons is more limited in mild AD patients with earlier stage disease (Davis et al., 1999). Third, cholinergic system change is only one of multiple pathobiological changes occurring in AD dementia and that the presence of dementia could not be explained by cholinergic system loss alone. This framework shift in AD is comparable to the dopamine-centric model of PD where post-mortem observations of extra-nigral and extra-cerebral Lewy body pathology resulted in a paradigmatic shift about the pathophysiology of this disorder (Braak et al., 2003). Interestingly, emerging evidence suggests that the cholinergic system is not a static 'layer' in this multi-system model of dementia but may play a dynamic and interactive role with other changing systems, including wide scale neural networks and interactions with other neurotransmitter systems in local networks (N. I. Bohnen, Grothe, Ray, Muller, \& Teipel, 2018).

The cholinergic hypothesis of dementia has resulted in a wealth of new information about the cholinergic system not only in the brain but also in the body. The distinct regional cerebral biodistribution of cholinergic nerve terminals in the brain implies biological functions that extend well beyond cognition. We will discuss the emerging dynamic and interactive role of the cholinergic system within a more complex multi-system pathophysiological model of PD and dementia. We will also review molecular cholinergic imaging studies in PD and discuss how disease-specific cholinergic changes are not only relevant for cognitive but also for motor, olfactory, mood, sleep and autonomic organ changes in this disorder. Finally, emerging observations implying compensatory versus 
neuro-inflammatory hypercholinergic system findings in prodromal LRRK2 PD will be discussed.

\section{MOLECULAR IMAGING TECHNIQUES TO STUDY CHOLINERGIC SYSTEM CHANGES IN PD}

Molecular imaging ligands have been developed for both positron emission tomography (PET) and single photon emission computed tomography (SPECT) to allow in vivo visualization of presynaptic, synaptic and post-synaptic cholinergic neurotransmission targets. Figure 1 provides an overview of the major PET and SPECT cholinergic imaging ligands.

The first cholinergic PET ligands were successfully developed in the early to mid-1990s and were small lipophilic ester substrate serving as acetylcholine analogues for the acetylcholinesterase (AChE) enzyme: $\left[{ }^{11} \mathrm{C}\right]$-methyl-4-piperidyl acetate $\left(\left[{ }^{11} \mathrm{C}\right]-\mathrm{MP} 4 \mathrm{~A}\right)$ and $\left[{ }^{11} \mathrm{C}\right]$-Methyl-4-piperidinyl propionate $\left(\left[{ }^{11} \mathrm{C}\right]\right.$-PMP) (Irie, Fukushi, Akimoto, Tamagami, \& Nozaki, 1994; Irie et al., 1996; Kilbourn, Snyder, Sherman, \& Kuhl, 1996). A more recent AChE PET ligand is 5-[ $\left[{ }^{11} \mathrm{C}\right]$-methoxy-donepezil ([ $\left.{ }^{11} \mathrm{C}\right]$-donepezil) (Hiraoka et al., 2012). Although these $\mathrm{AChE}$ ligands bind to the enzyme at the synaptic space, pre- and postsynaptic membrane, histochemistry studies from the 1960s have shown that AChE provides a good measure of the integrity of pre-synaptic cholinergic nerve terminals (Shute \& Lewis, 1966). Another advantage of the AChE PET ligands is that the enzyme hydrolysis rates in low and moderate binding areas, such as the neocortex, limbic cortex and thalamus can be assessed non-invasively (Koeppe et al., 1999; Nagatsuka et al., 2001). A disadvantage of AChE PET ligands is that the relatively low sensitivity in measuring subcortical or deep cortical structures limiting the identification of potential specific non-cortical disease markers (Marcone et al., 2012). There are currently no ligands targeting the acetylcholine synthetic enzyme choline acetyltransferase. However, both SPECT (-)-5-[ $\left.{ }^{123} \mathrm{I}\right]-$ Iodobenzovesamicol ([ $\left.\left.\left.{ }^{123} \mathrm{I}\right]-\mathrm{IBVM}\right), \mathrm{IBVM}\right)$ and PET $\left[{ }^{18} \mathrm{~F}\right]$-Fluoroethoxybenzovesamicol ( $\left[{ }^{18}\right.$ F]-FEOBV) (D. E. Kuhl et al., 1994; Mulholland et al., 1998) ligands target the vesicular acetylcholine transporter (VAChT). An advantage of the VAChT ligands is that high binding areas, including the striatum and cerebellar vermis, can be estimated (Petrou et al., 2014). Furthermore, simplified delayed imaging acquisition protocols using reference tissues have been validated for $\left[{ }^{18} \mathrm{~F}\right]$-FEOBV. Although the cerebellar gray matter reference region (Petrou et al., 2014) may be suitable for disorders that do not affect this brain region, this may have limited utility for parkinsonian disorders where pathology may affect the cerebellum. In this respect, the use of a white matter reference region may be preferred (Aghourian et al., 2017).

Ionotropic nicotinic cholinergic (nAChR) and metabotropic muscarinic (mAChR) receptors mediate cholinergic neurotransmission. There are several SPECT and PET ligands that bind to $\mathrm{nAChR}$ and $\mathrm{mAChR}$ receptors. Nicotinic receptor ligands may have receptor subtype nonspecific binding like $\left[{ }^{11} \mathrm{C}\right]$-nicotine or target specific receptor subtypes, like a $4 \beta 2 * \mathrm{nAChR}$ (e.g., $\left[{ }^{18} \mathrm{~F}\right]$-Flubatine PET, 2-[ $\left.{ }^{18} \mathrm{~F}\right]-\mathrm{FA}-85380$ PET or 5-[ $\left.{ }^{123} \mathrm{I}\right]$-iodo-3-[2(S)-2azetidinylmethoxy]pyridine ([$\left.{ }^{123} \mathrm{I}\right] 5$-IA) SPECT or a 7 nAChR $\left[{ }^{18} \mathrm{~F}\right]$-ASEM (Horti et al., 
2014; Saji et al., 2002; Smits et al., 2014). An advantage of the $\left[{ }^{18}\right.$ F]-Flubatine PET ligand is that this ligand can be performed with a relatively short imaging protocol (Sabri et al., 2018). Muscarinic brain SPECT ligands include [ $\left.{ }^{123} \mathrm{I}\right]$-iodo-quinuclidinyl-benzilate ([ $\left.{ }^{123} \mathrm{I}\right]-$ QNB) targeting M1/M4 mAChR (Colloby et al., 2006). [ $\left.{ }^{11} \mathrm{C}\right]-\mathrm{N}$-methyl-4-piperidyl benzilate ([ $\left.\left.{ }^{11} \mathrm{C}\right] \mathrm{NMPB}\right)$ is a brain PET mAChR ligand (Asahina et al., 1998).

There are prominent regional cerebral differences in cholinergic ligand binding that reflect topographic differences in specific cholinergic projections and acetylcholine-mediated brain functions. The different cholinergic projections arising from different originating cholinergic cell groups that have been numbered (M. M. Mesulam, 1996). For example, the Ch1 (medial septal nucleus) and the $\mathrm{Ch} 2$ cell groups (vertical limb nucleus of the diagonal band) project to the hippocampus; the $\mathrm{Ch} 3$ groups (horizontal limb nucleus of the diagonal band) projects to the olfactory bulb. A major group is $\mathrm{Ch} 4$, which includes the nucleus basalis of Meynert (nbM) and projects to the cortical amygdala and the cortical mantle (M. Mesulam, Mufson, Levy, \& Wainer, 1983). Ch5 (pedunculopontine nucleus, PPN) and Ch6 (laterodorsal tegmental complex (LDTC) cell groups provide major cholinergic inputs to the thalamus, cerebellum, other brainstem nuclei and subsets of the striatum (Heckers, Geula, \& Mesulam, 1992; M.M. Mesulam, Mufson, Wainer, \& Levy, 1983). Notably, these are separate from striatal cholinergic interneurons that have a local origin (Fibiger, 1982; M. Mesulam, Mash, Hersh, Bothwell, \& Geula, 1992). Table 1 lists the major cholinergic cell groups and their projection areas. Although cholinergic molecular imaging techniques have mainly focused on imaging the projection areas to assess the integrity of cholinergic neurons in the primary cell group, increasing camera resolution will allow direct visualization and quantification of cholinergic binding in primary cell groups. Cholinergic molecular imaging can also assess striatal cholinergic interneurons and cerebellar cholinergic nerve terminals.

In vivo PET imaging shows striking differences in regional cerebral uptake among the different analogues of the cholinergic system. For example, figure 2 shows a comparison of the normal biodistribution of AChE $\left[{ }^{11} \mathrm{C}\right]-\mathrm{PMP}$, VAChT $\left[{ }^{18} \mathrm{~F}\right]-\mathrm{FEOBV}$ and $\mathrm{a} 4 \beta 2 * \mathrm{nAChR}$ $\left[{ }^{18} \mathrm{~F}\right]$-Flubatine ligands in the same PD patient. The VAChT and AChE ligands show intense uptake in the basal ganglia followed by the thalamus. Striking cerebellar differences are noted with intense VAChT uptake in the vermis whereas the AChE shows intense uptake in the cerebellar hemisphere. Flubatine shows most intense uptake in the thalamus with more diffuse and mild uptake in the remainder of the brain. There is relatively low AChE uptake in the hippocampus and temporal cortex whereas the VAChT ligand does show more prominent hippocampal activity.

\section{CHOLINERGIC SYSTEM CHANGES IN PD AND PARKINSONIAN DEMENTIA}

Patients with PD are at high risk of developing dementia. Parkinsonian dementia can be clinically defined as either PD with dementia (PDD) or dementia with Lewy bodies (DLB). DLB has a more early manifestation of cognitive and neuropsychiatric symptoms coinciding within one year of the onset of motor impairments (N. I. Bohnen, Muller, \& Frey, 2017). This is in contrast to clinically defined PDD where there is a longer period of predominant 
motor impairments of at least a year before the emergence of cognitive decline. Early in vivo VAChT and AChE imaging studies in PD consistently showed that the presence of dementia in PD was associated with more severe and extensive cortical cholinergic losses compared to PD without dementia (N. I. Bohnen et al., 2003; D. Kuhl et al., 1996), which was confirmed by subsequent studies (Table 2 ).

We found heterogeneous cholinergic changes in PD patients without dementia where cortical and thalamic AChE hydrolysis rates are normal in about one third and one sixth, respectively, of these patients (N. I. Bohnen et al., 2012). The majority of patients with reduced thalamic AChE hydrolysis rates also had reduced cortical AChE levels but the reverse was generally not the case. This may suggest that CBFB losses may precede PPN/ LTDC cholinergic cell losses. The heterogeneity of cholinergic system changes in PD without dementia is also associated with specific cognitive changes, including executive function, attention and memory deficits (N. I. Bohnen et al., 2015; N. I. Bohnen et al., 2012). Interestingly, we found a near linear relationship between the number of cortical hypocholinergic patients and global cognitive scores (N. I. Bohnen et al., 2015). More specifically, abnormal cortical cholinergic activity was present in over $80 \%$ of PD patients with a global cognitive Z-score of more than 2 standard deviations from normal (Figure 3). These data suggest that cholinergic system changes are a major driver across the spectrum of cognitive changes in PD. The earliest cortical AChE changes may occur in the occipital cortex (especially Brodman area 18) in patients with PD without dementia (Shimada et al., 2009). The early involvement of the posterior neocortex and associated visuoperceptual impairment perhaps may be risk factors for rapid symptomatic progression and ultimately dementia in PD.

Cortical cholinergic changes are consistently most severe and extensive in parkinsonian dementia subtypes compared to PD without dementia (Muller \& Bohnen, 2013). However, we previously did not find significant cholinergic changes between the clinically defined parkinsonian dementia PDD versus DLB subtypes (N. I. Bohnen et al., 2017). A recent VAChT $\left[{ }^{123} \mathrm{I}\right]$-IBVM SPECT study in patients with clinically defined DLB found prominent cortical reductions in the patients compared to normal control subjects (Mazere, Lamare, Allard, Fernandez, \& Mayo, 2017). In addition, prominent reductions were observed in subcortical regions, including the thalamus and striatum, but not in the hippocampus (Table $3)$.

Nicotinic AChR molecular imaging studies have shown decreased subcortical binding with the majority of the studies also showing decreased cortical nAChR activity (see table 4 for summary listing of studies).

Nicotinic AChR molecular imaging studies have found significant correlations between regional cerebral receptor binding changes and cognitive changes in PD. An a $4 \beta 2 * n A C h R$ $2-\left[{ }^{18} \mathrm{~F}\right]-\mathrm{FA}-85380$ PET study found weak correlations with reduced nAChR binding in the thalamus, midbrain, temporal cortex, hippocampus, and cerebellum in non-demented patients with PD (Meyer et al., 2009). A [ $\left.{ }^{123} \mathrm{I}\right]-5-\mathrm{IA}-85380 \mathrm{nAChR}$ bran SPECT study found significant correlations between performance on the Boston Naming Test and Word List Intrusions and $\mathrm{nAChR}$ binding in cortical (the right superior parietal lobule) and subcortical 
areas (the left thalamus, the left posterior subcortical region, and the right posterior subcortical region) in the PD patients.

Muscarinic AChR molecular imaging studies in PD are few but have shown evidence of increased receptor binding in the frontal lobe in patients with PD and increased binding in the occipital lobe in parkinsonian dementia (see table 5 for summary listing of studies). An increase in $\mathrm{mAChR}$ expression seen in some in vivo neuroimaging studies has been interpreted as upregulation in the setting of loss of afferent cholinergic projections. An early $\left[{ }^{11} \mathrm{C}\right] \mathrm{NMPB}$ mAChR brain PET study did not find significant correlations between cerebral $\mathrm{mAChR}$ binding and cognition in PD without dementia despite the presence of frontal upregulation of receptor binding (Asahina et al., 1998). A more recent covariance study points to significant associations between bidirectional $\mathrm{mAChR}$ binding changes and cognition in PDD (see section on large-scale cognitive networks for more discussion below).

\subsection{Mixed cognitive effects of neurotransmitter changes and protoneiopathies in PD}

The etiology of cognitive impairment in PD is multifactorial (Kalia, 2017). In vivo neuroimaging biomarkers not only include targets to measure neurotransmission, but also markers to investigate proteinopathy (e.g., a-syncleinopathy, $\beta$-amyloidopathy, tauopathy), neuronal and synaptic functions (e.g., glucose metabolic or cerebral blood flow) and brain network connectivity (Kalia, 2017). We have observed that neurotransmitter changes, such as altered cholinergic system changes, play a particular important role in cognitive symptoms and that failure of this system may aggravate the severity of cognitive impairment in this disorder.

Dual ligand $\left[{ }^{18} \mathrm{~F}\right]-$ Fluorodopa (FDOPA) dopaminergic and AChE $\left[{ }^{11} \mathrm{C}\right]-\mathrm{MP} 4 \mathrm{~A}$ PET studies obtained in PD and PDD patients showed that cholinergic but not dopaminergic losses were a key importance of distinguishing PDD from PD patients (Hilker et al., 2005; Klein et al., 2010). This does not necessarily mean that cholinergic losses are a single driver of the dementia process; it should be seen in the context of nigrostriatal and limbofrontal dopaminergic loss. It is the combination (and interaction) of both dopaminergic and cholinergic losses that may play an important role in the etiology of cognitive impairment in PD.

Kehagia et al. proposed a 'dual-syndrome' hypothesis of cognitive impairment in PD where early and/or mild cognitive impairment, especially fronto-executive dysfunction, may be driven by frontostriatal dopaminergic losses whereas conversion to dementia in PD might depend on non-dopaminergic, cholinergic more posterior cortical dysfunctions (Kehagia, Barker, \& Robbins, 2010). The 'dual-syndrome' hypothesis provides a useful conceptual framework to investigate progressive cognitive decline in PD but does not emphasize possible interactive effects between dopaminergic and cholinergic system functions. Recently, we reported on the so-called 'compensatory' hypothesis to better understand dynamic changes in both dopaminergic and cholinergic systems in PD (N. I. Bohnen et al., 2015; Kim, Bohnen, Muller, \& Lustig, 2018). The 'compensatory' hypothesis posits that frontostriatal dopaminergic losses may lead to compensatory reliance in cortical cholinergic circuits. This was based on the observation that the dopaminergic and cholinergic system did not only have independent incremental but also interactive effects in predicting cognitive 
impairment in PD. More specifically, combined dopaminergic and cholinergic losses were associated with greater degree of cognitive impairment, in particular executive functions $(\mathrm{N}$. I. Bohnen et al., 2015). Impairment in executive functions is a strong predictor of dementia in PD (Ewers et al., 2012; Levy, 2007), possibly explaining why combined cholinergic and dopaminergic deficits predispose to PDD. Conversely, preservation of cholinergic innervation in the setting of dopaminergic losses may attenuate cognitive impairment in PD. This is illustrated by PD patients who have prominent loss of caudate nucleus dopaminergic nerve terminals yet have normal range cognitive performance in the setting of preserved cholinergic functions.

The presence of $\beta$-amyloid plaques has been associated with dementia in post-mortem PD studies (Kotzbauer et al., 2012). We previously reported that in vivo visualization of $\beta$ amyloid plaques in PD was associated with more severe cognitive impairment that was not only independent but also incremental of nigrostriatial dopaminergic and cortical cholinergic losses (Shah et al., 2016). These observations underscore the multifactorial etiology of cognitive impairment in PD.

\subsection{Cortical top-down and thalamic bottom-up cholinergic attentional functions in PD}

Different cholinergic projections may serve different aspects of cognition. We compared cholinergic cortical top-down and cholinergic thalamic bottom-up functions and the ability to resist a distractor while performing an attentional task in non-demented patients with PD (Kim, Muller, Bohnen, Sarter, \& Lustig, 2017a). PD patients performed comparably to healthy controls in the precision of attention-dependent judgments of duration and in sustaining attention over time. However, PD patients' performance was strikingly more impaired by the introduction of a distractor. Cortical-cholinergic integrity, but not thalamiccholinergic or striatal-dopaminergic integrity, mediated the effect of the distractor on task performance. These results demonstrate that the basal forebrain cortical cholinergic system serves a specific role in executing top-down control to resist external distraction. In contrast, analysis of findings obtained in a signal detection task showed that thalamic cholinergic innervation was involved in target detection (but not rejection), indicating a specific contribution to bottom-up salience processing in PD patients without dementia (Kim, Muller, Bohnen, Sarter, \& Lustig, 2017b). Together, these results illustrate regionally specific contributions of cholinergic function to different aspects of attention. These regionspecific changes may affect the ability of PD patients to successfully switch between different cognitive networks that are involved in processing of intrinsic versus extrinsic stimuli, resulting in compromised cognitive and behavioral flexibility.

\subsection{Large-scale cognitive networks and cholinergic system changes in PD and parkinsonian dementia}

A number of distinct large-scale brain networks subserving cognitive functions have been identified (Yeo et al., 2011). There is emerging recognition of the modulatory role of neurotransmitters in these networks and how these change with dementing disease processes (Gratwicke, Jahanshahi, \& Foltynie, 2015), including PD (Luo et al., 2015). The cholinergic system may play an important role in modulating these networks. Cognitive decline in PD may be the result of deteriorated brain network integrity secondary to cholinergic loss. For 
example, spatial covariance analyses of nicotinic and muscarinic cholinergic imaging studies have been performed and show how changes in inter-connected brain regions may relate to cognitive changes in parkinsonian dementia. Table 6 lists a summary of the major findings of cholinergic receptor changes within large-scale brain networks in parkinsonian dementia. Findings show concomitant areas of decreased as well as increased receptor ligand bindings (Colloby et al., 2016). Furthermore, a mAChR brain [ $\left.{ }^{123} \mathrm{I}\right]-\mathrm{QNB}$ SPECT study in patients with PDD found increased or preserved receptor binding in regions overlapping with key nodes of the default mode network and frontoparietal networks. These findings suggest that the cholinergic system may play a modulatory role within these networks (Colloby et al., 2016). Bidirectional changes in regional receptor expression may suggest the presence of compensatory responses to neurodegenerative injury in some brain areas in the setting of decompensation or degeneration in other regions (N. I. Bohnen et al., 2018).

\section{MOBILITY IMPAIRMENTS: FALLS, GAIT SPEED, FREEZING OF GAIT AND POSTURAL CONTROL}

Upright walking in a complex environment is heavily dependent on cognitive control mechanisms to detect and avoid obstacles to prevent falls and ensure safe ambulation. Therefore, neural pathways subserving cognition may also serve mobility functions (Yarnall, Rochester, \& Burn, 2011; Yogev et al., 2005). This is clinically evident as cognitive impairment is a risk factor for falls and axial motor impairments indicate an increased risk of dementia in PD (Alves, Larsen, Emre, Wentzel-Larsen, \& Aarsland, 2006; Yarnall et al., 2011). It has been proposed that the loss of striatal dopamine in PD imposes increased demands for compensation on other brain systems, including cholinergic systems (basal forebrain, PPN) involved in attentional function and the control of gait and posture, and that the subsequent loss of these systems contributes significantly to the progressive dopamineresistant gait abnormalities that characterize later stages of the disease (N. I. Bohnen \& Albin, 2011; Kucinski, Paolone, Bradshaw, Albin, \& Sarter, 2013; Lord, Rochester, Hetherington, Allcock, \& Burn, 2010; Sarter, Albin, Kucinski, \& Lustig, 2014; Yarnall et al., 2011).

Falling represent a serious mobility impairment in PD. We found that brainstem-thalamic more than cortical AChE binding losses were associated with fall status in PD without dementia independent from nigrostriatal dopaminergic losses (N. I. Bohnen et al., 2009; N. I. Bohnen et al., 2012). Reduced brainstem-thalamic AChE hydrolysis rates associated with impaired sensory processing during postural control in patients with PD (Muller et al., 2013). It should be noted that the majority of patients with PD who have reduced brainstemthalamic cholinergic function also have reduced forebrain cortical cholinergic losses (N. I. Bohnen et al., 2012) implicating cholinergic system changes that are more extensive. Subsequent post-mortem studies have confirmed more severe cholinergic neuronal loss in PD fallers compared to non-fallers (Karachi et al., 2010). There is also converging evidence from drug studies for a cholinergic role in the pathophysiology of falls. A number of cholinesterase inhibitor trials have shown significant fall reductions in patients with PD treated with these drugs compared to placebo (Chung, Lobb, Nutt, \& Horak, 2010; 
Henderson et al., 2016). A rivastigmine treatment study showed also evidence of improved gait speed and gait variability in PD (Henderson et al., 2016).

The etiology of falls is heterogeneous in PD and may be due to poor postural control, cognitive impairment, freezing of gait, autonomic changes with orthostasis and other factors (Ashburn, Stack, Ballinger, Fazakarley, \& Fitton, 2008; Gazibara et al., 2016; Rudzinska et al., 2013). Therefore, cholinergic mechanism underlying propensity to falls is unlikely to be explained by impairment of a single brain region. For example, we found that patients with $\mathrm{PD}$ and freezing of gait (a major reason for falls) had more severe cortical cholinergic losses rather than brainstem-thalamic changes (N. I. Bohnen et al., 2014). A limitation of the AChE $\left[{ }^{11} \mathrm{C}\right]$-PMP PET ligand is that this ligand is not optimized for striatal estimation of ligand binding, thereby limiting assessment of possible freezing-specific striatal biomarkers. Furthermore, findings of our study also showed that the freezers had more abnormal cortical $\beta$-amyloid plaques and more severe nigrostriatal dopaminergic losses suggesting a complex interplay of pathomechanistic factors. The heterogeneous presence of different biomarkers of freezing of gait may not only reflect the complex pathophysiology of this episodic motor disturbance but also the presence of different freezing of gait sub-types, such as freezing associated with more severe end-stage PD or freezing associated with limited cognitive and sensorimotor processing capacities (Nieuwboer \& Giladi, 2013).

Reduced cortical AChE hydrolysis rates associated with slow gait speed in PD (N. I. Bohnen et al., 2013). Interestingly, the subset of patients with preserved cortical cholinergic functions had normal range gait speed despite the presence of prominent nigrostriatal dopaminergic degeneration. This may represent adaptive plasticity of the cholinergic system in the setting of relatively isolated dopaminergic losses in early or mild PD. Once the cholinergic system starts to fail, compensation will break down manifesting with slow gait speed, more cognitive impairment and other symptoms.

\section{DYSKINESIAS}

Although levodopa remains the mainstay of dopaminergic pharmacotherapy in PD, its longterm use is associated with significant motor complications, including motor fluctuations and dyskinesias. For example, nearly half of the PD patients may develop levodopa-induced dyskinesias (Ahlskog \& Muenter, 2001). It has been suggested that nicotinic receptors may play a putative role in the etiology of levodopa-induced dyskinesias in PD, although dopaminergic, serotonergic, glutamatergic, adenosinergic and opioid systems and phosphodiesterase 10A levels have also been implicated (Pagano, Yousaf, \& Politis, 2017). For example, animal studies have shown that both nicotine and nicotinic receptor agonist drugs reduced levodopa-induced dyskinesias by over $50 \%$ in parkinsonian rodent and monkey models (Quik, Bordia, Zhang, \& Perez, 2015). A [ ${ }^{123}$ I]-5-IA brain nAChR SPECT study found that the density of nicotinic receptors in the caudate nucleus was significantly higher in dyskinetic PD patients compared to nondyskinetic patients (Brumberg et al., 2017). Findings were most prominent contralateral to the most affected body side. There was no significant difference in striatal dopamine transporter binding between the two patients groups. These observations suggest that altered expression of caudate nucleus nAChR may play a role in the pathogenesis of levodopa-induced dyskinesias in patients with PD. 


\section{OLFACTION}

Impaired olfaction is an early non-motor manifestation of $\mathrm{PD}$ and may be present in the prodromal stage of the disease and likely before mid-brain dopaminergic losses occur (Doty, 2012; Perez-Lloret \& Barrantes, 2016). Although the presence of Lewy body pathology and other proteineopathies have been associated with olfactory impairments in PD, changes in neurotransmitters, including acetylcholine, may also play a role (N. I. Bohnen \& Muller, 2013; D’Souza \& Vijayaraghavan, 2014). We found that olfactory functions were associated with limbic AChE $\left[{ }^{11} \mathrm{C}\right]$-PMP binding losses while taking into account the degree of neocortical cholinergic and nigrostriatal dopaminergic activity (N.I. Bohnen et al., 2010). Olfactory performance was also associated with memory functions suggesting that more severe hyposmia may be a marker of increased risk of cognitive impairment in PD. This hypothesis was confirmed in a subsequent prospective cohort study where the presence of more severe hyposmia at baseline predicted higher risk of incident dementia in PD (Baba et al., 2012).

\section{SLEEP}

Rapid eye movement (REM) sleep behavior disorder (RBD) is a common parasomnia in PD. The presence of RBD has been identified as a risk factor for dementia in PD (Gagnon et al., 2009; Marion, Qurashi, Marshall, \& Foster, 2008) raising the possibility that the cholinergic system may play a role in its pathophysiology. We found that reduced brain cholinergic activity associated with RBD in PD (Kotagal, Albin, et al., 2012). Patients with PD and RBD had lower thalamic (-9.1\%), limbocortic (-8.3\%) and neocortical (-9.8\%) AChE $\left[{ }^{11} \mathrm{C}\right]-$ PMP binding compared to PD patients without this sleep disorder. Cholinergic changes, especially in brainstem and subcortical circuits, may contribute to this parasomnia. A recent CBFB cholinergic density MRI study also found an associated between Ch4 group lower forebrain density and this parasomnia in PD (Barrett, Blair, Sperling, Smolkin, \& Druzgal, 2018). Although the CBFB does not directly assess cholinergic projections to subcortical areas, the reported association between density losses in CBFB and this parasomnia may reflect a parallel decline in the different cholinergic projection areas in PD (N. I. Bohnen et al., 2012). Our findings suggest that the integrity of the cholinergic system may be a determinant of this parasomnia. However, it should be noted that he pathophysiology of RBD is complex and involves changes in multiple circuits and neurotransmitters beyond the cholinergic system likely in a dynamic and interactive way.

\section{DEPRESSION}

Mood disturbances, including depression, are common neuropsychiatric disturbances in PD. Multiple monoaminergic neurotransmitter changes, in particular serotonin and norepinephrine, play a role in depression (Remy, Doder, Lees, Turjanski, \& Brooks, 2005) and have become the mainstay of pharmacotherapy for this mood disorder in PD (Weintraub et al., 2005). Depression is also a common comorbidity in cognitive impairment in PD suggesting a potential pathophysiological role of the cholinergic system. We previously reported on $\mathrm{AChE}\left[{ }^{11} \mathrm{C}\right]$-PMP PET findings in patients with PD and parkinsonian dementia and found decreased cortical cholinergic activity was associated with increased depressive 
feeling while taking into account the degree of cognitive impairment (N. I. Bohnen et al., 2007). A a $4 \beta 2$ nAChR 2- $\left[{ }^{18}\right.$ F]FA-85380 PET study found associations between depressive symptoms and reduced nAChR binding in the anterior cingulate cortex, putamen, midbrain, and occipital cortex in non-demented patients with PD (Meyer et al., 2009). Treatment with cholinesterase inhibitor drugs has a;sp shown improvement in depression in patients with PDD (Ishikawa, Motoi, Mizuno, Kubo, \& Hattori, 2014). These findings imply a potential role of the cholinergic system in depression in PD, at least in the setting of cognitive impairment.

\section{VISUAL HALLUCINATIONS}

Visual hallucinations are prominent in parkinsonian dementia and are one of the core clinical diagnostic features of DLB (McKeith et al., 2017). Improvement in visual hallucinations with donepezil treatment in patients with DLB suggests a possible role of the cholinergic system in the pathophysiology of visual hallucinations in these patients. This is also illustrated by the common clinical experience that the use of anti-cholinergic drugs in patients with PD may induce hallucinations. A $\left[{ }^{11} \mathrm{C}\right]-\mathrm{MP} 4 \mathrm{~A}$ AChE PET study found evidence of reduced cortical cholinergic activity in PD patients with hallucinations compared to non-hallucinating patients (Shinotoh et al., 1999). A [ ${ }^{123}$ I]-5-IA-85380 nAChR brain SPECT study in patients with DLB study suggests widespread cortical and subcortical $\mathrm{nAChR}$ reductions except for increased occipital lobe activity in DLB, a change most pronounced in subjects with a recent history of visual hallucinations.(O'Brien et al., 2008). These preliminary observations and topographic association with $\mathrm{nAChR}$ changes in the occipital cortex imply an involvement of the cholinergic system in the pathophysiology of visual hallucinations, at least in patients with DLB.

\section{FATIGUE}

Fatigue is a common and disabling non-motor symptom in PD. A single AChE $\left[{ }^{11} \mathrm{C}\right]-\mathrm{PMP}$ PET study showed that neither thalamic nor cortical AChE binding was a significant predictor of fatigue in PD (Chou, Kotagal, \& Bohnen, 2016). This observation suggests that, at least for cortical or thalamic brain regions, the cholinergic system does not play a significant role in fatigue in PD. However, further research using other ligands, such as $\mathrm{nAChR}$ tracer, is needed to further investigate this area.

\section{RISK TAKING BEHAVIOR AND DRIVING IN PATIENTS WITH PD}

Driving is a complex visuomotor, perceptual and cognitive task that can be impaired in patients with PD. A $\left[{ }^{11} \mathrm{C}\right]-\mathrm{PMP}$ AChE PET study found evidence of reduced brainstemthalamic but not cortical AChE binding in PD patients with a reported history of risk driving (i.e., had a traffic citation, had been pulled over or involved in an accident since the onset of PD) compared to safe drivers (Weathers, Kotagal, Bohnen, \& Chou, 2014). There were no significant differences in striatal dopaminergic activity between the two groups. These findings may relate to deficiency of bottom-up salience signal detection associated with the presence of thalamic cholinergic hypofunction (Kim et al., 2017b). Alternatively, findings may relate to impaired integration of sensory and motor data (Perez-Lloret \& Barrantes, 
2016). These observations may have implications for giving driving advice to patients with PD.

\section{PERIPHERAL CHOLINERGIC AUTONOMIC ORGAN CHANGES IN PD}

Autonomic changes are common in PD and may be caused by central or peripheral nervous system sympathetic and parasympathetic changes due to Lewy body pathology (Beach et al., 2010; Wong et al., 2012). Cholinergic neurons provide sympathetic innervation to the skin and parasympathetic autonomic innervation to peripheral organs (Perez-Lloret \& Barrantes, 2016). AChE PET imaging using the $\left[{ }^{11} \mathrm{C}\right]$-donepezil ligand has been used to investigate presumed parasympathetic changes of peripheral gastrointestinal organs (Gjerloff et al., 2014). Small ester AChE substrate ligands like [ $\left.{ }^{11} \mathrm{C}\right]-M P 4 A$ lack peripheral organ trapping preventing the use of $\left[{ }^{11} \mathrm{C}\right]$-MP4A PET imaging outside the brain (Gjerloff et al., 2014). Gjerlpff and colleagues report on significant reductions of $\left[{ }^{11} \mathrm{C}\right]$-donepezil uptake in small intestine $(-35 \%)$, pancreas $(-22 \%)$ and only mild reductions in the myocardium $(-9 \%)$ in patients with early to moderate PD (duration of disease less than 5 years) compared to normal control subjects (Gjerloff et al., 2015). No correlations were found between the $\left[{ }^{11} \mathrm{C}\right]$-donepezil signal and disease duration, severity of constipation, gastric emptying time, and heart rate variability. A subsequent $\left[{ }^{11} \mathrm{C}\right]$-donepezil PET study in patients with newly diagnosed PD (duration of disease les than 1.5 years) found reduced $\left[{ }^{11} \mathrm{C}\right]$-donepezil uptake in the small intestine $(-14 \%)$, colon $(-22 \%, p<0.001)$, and kidneys (14\%) (Fedorova et al., 2017). No differences in myocardial or pancreatic AChE levels were seen. The differences between the two studies may suggest a variable time course for loss of parasympathetic innervation of the pancreas, small intestine, and colon (Fedorova et al., 2017). AChE is not a specific marker for vagal cholinergic parasympathetic nerve terminals and may bind to several tissue types with the ability to produce AChE (Fedorova et al., 2017). Peripheral lymphocytes express choline acetyltransferase, vesicular acetylcholine transporters, AChE, and muscarinergic receptors (Kawashima, Fujii, Moriwaki, \& Misawa, 2012). Activated lymphocytes may manifest upregulated AChE activity (Kawashima et al., 2012). For example, $\left[{ }^{11} \mathrm{C}\right]$-donepezil PET imaging may be able to detect nonneuronal cholinergic activity in infections (Gjerloff et al., 2014). An abundance of enteric neurons are cholinergic and express AChE (Anlauf, Schafer, Eiden, \& Weihe, 2003). Therefore, decreased $\left[{ }^{11} \mathrm{C}\right]-$ donepezil signal (i.e., AChE density) in the gut could also be caused by loss of enteric neurons as well as vagal efferents (Anlauf et al., 2003). However, PD is not associated with gastrointestinal myenteric ganglion neuron loss (Annerino et al., 2012). Therefore, neuropathology in myenteric neurons is unlikely to be a causative factor in PD-related gastrointestinal dysmotility. Cholinergic imaging of autonomic nervous system may have the potential to identify prodromal stage PD.

\section{Hypercholinergic system findings in prodromal LRRK2 PD: Compensation, microglial inflammation or both?}

Mutations in leucine-rich repeat kinase 2 (LRRK2) are a common cause of genetic PD (Kalia et al., 2015). The clinical features of manifesting LRRK2 mutation carriers are generally indistinguishable from those of patients with sporadic PD but the non-motor 
features of LRRK2 PD may be less prominent, include better olfactory performance, and less cognitive decline, compared to idiopathic PD (Healy et al., 2008). Recently, Liu et al. reported on in vivo imaging of cerebral $\mathrm{AChE}$ using $\left[{ }^{11} \mathrm{C}\right]-\mathrm{PMP} P E T$ in a series of asymptomatic and manifesting carriers of LRRK2 mutations and compared them to idiopathic PD and non-PD control subjects (Liu et al., 2018). The investigators found that the nonmanifesting LRRK2 mutation carriers had increased AChE hydrolysis rates compared to healthy controls in cortical regions. Manifest LRRK2-PD patients had significantly higher AChE activity compared to that of the idiopathic PD patients in not only cortical but also thalamic regions. The authors concluded that LRRK2 mutations are associated with significantly increased cholinergic activity in the brain in non-manifesting carriers compared to healthy controls and in LRRK2-PD patients compared to idiopathic PD. Findings of hypercholinergic activity in the non-manifesting LRRK2 mutation carriers may be compatible with a compensatory mechanism as previous dopamine nerve terminal imaging have shown the presence of nigrostriatal losses in some of these carriers .(Adams et al., 2005). The manifesting LRRK2 PD patients had relatively intact cognition, which may be compatible with preserved or increased cortical cholinergic activity.

There is also evidence for a relevant role of inflammation in the pathogenesis of LRRK2 associated PD, as LRRK2 is highly expressed in macrophages and microglia suggesting an involvement in inflammatory pathways (Brockmann et al., 2016). There are two principal cholinesterases in the human brain: $\mathrm{AChE}$ and butyrylcholinesterase (BuChE). AChE has a neuronal and BuChE a neuroglial distribution (Wright, Geula, \& Mesulam, 1993). BuChE enzymatic activity plays an important role in regulating intrinsic inflammation and activity of cholinoceptive glial cells (Darreh-Shori et al., 2013). In this respect it is noteworthy that the AChE $\left[{ }^{11} \mathrm{C}\right]$-PMP radioligand has limited hydrolysis by butyrylcholinesterase (Snyder et al., 1998), this radiotracer may represent limited uptake by neuroglial BuChE, and as such, part of the PMP radiotracer signal may reflect a neuro-inflammatory component.

Hypercholinergic activity has previously been reported in patients with mild cognitive impairment at risk of Alzheimer disease. For example, DeKoskey and colleagues have shown upregulation of choline acetyltransferase activity in hippocampus and frontal cortex of elderly subjects with mild cognitive impairment but not in AD (DeKosky et al., 2002). These findings imply a transient, region-specific cholinergic neuroplastic response at the early stage of dementia. A subsequent study from the same group found that superior frontal cortical choline acetyltransferase-immunoreactive fiber and axon varicosity densities were not altered in the mild cognitive impairment group but were significantly reduced in the group with $\mathrm{AD}$ and correlated with impaired frontal lobe and global cognitive function (Ikonomovic et al., 2007). These authors concluded that the lack of an increase in cholinergic axonal innervation suggests that not a structural reorganization of cholinergic profiles but a biochemical up-regulation of choline acetyltransferase protein or enzyme activity levels may compensate for decreased regional cholinergic fibers and axon varicosities (Ikonomovic et al., 2007). There is also evidence of up-regulation of a 7 nicotinic acetylcholine receptors (nAChRs) in nucleus basalis neurons that may signal a compensatory response to maintain basocortical cholinergic activity during progression of AD (Counts et al., 2007). Similar pathophysiological changes may explain hypercholinergic activity observed in some patients with idiopathic PD. 


\section{DISCUSSION}

Regional cerebral cholinergic system changes are heterogeneous in $\mathrm{PD}$, at least in the absence of dementia (N. I. Bohnen et al., 2012). Recent recognition of regionally distinct binding patterns of cholinergic neurotransmission ligands represent a departure of the long held belief that cholinergic system projections are more diffuse in the brain (Woolf, 1991). Furthermore, regional cerebral cholinergic structures appear to play functionally distinct role sranging from cognition, olfaction, sleep to motor impairments, in particular postural instability and gait difficulties (Muller \& Bohnen, 2013). The clinical relevance of regional cerebral cholinergic system changes may provide a new impetus for research to expand the clinical indications for cholinergic pharmacotherapy and/or invasive or non-invasive neuromodulation of cholinergic brain structures in order to alleviate specific motor and nonmotor symptoms in PD. Furthermore, cholinergic network adaptation may serve as a novel research target in PD (N. I. Bohnen et al., 2018).

Although the cholinergic system is only one element in the complex pathophysiology of dementia in PD, progressive cholinergic denervation has been recognized as an important neurodegenerative process across the spectrum of cognitive decline in PD (N. I. Bohnen et al., 2015). Effects of cholinergic degeneration should be placed in the context of severe dopaminergic losses in PD. The recently proposed 'compensatory' hypothesis of dopamine and acetylcholine neurotransmitter interaction effects suggest that interpretation of cognitive and other clinical changes in PD should not focus on a single system impairment but rather at combined effects of different neurotransmitter and other pathomechanistic system changes in PD (N. I. Bohnen et al., 2015). According to the 'compensatory' hypothesis, dual dopaminergic and cholinergic system changes may exacerbate cognitive deficits. In contrast, preservation of the cholinergic system in the setting of the typical prominent dopaminergic losses seen in PD may help to attenuate cognitive changes. Interestingly, the 'compensatory' hypothesis of dopaminergic and cholinergic neurotransmitter system changes has been supported by data from dual- versus single-system dopaminergic versus cholinergic lesioning studies (Kucinski, de Jong, \& Sarter, 2017). Rats with dual cholinergicdopaminergic lesions fell more frequently than single system lesioned rats. Falls in duallesioned rats were associated with incomplete rebalancing after slips and low traversal speed. Normal ladder rung walking and pasta handling performance indicated the absence of sensorimotor deficits. Sustained attention performance was impaired in dual-lesioned and single (cholinergic) system lesions rats; however, attentional performance and falls were correlated only in dual-lesioned rats. Furthermore, in dual-lesioned rats the placement and size of dopaminergic lesion correlated significantly with fall rates illustrating the importance of the presence of dopaminergic deficits. The results support the hypothesis that after dual cholinergic-dopaminergic lesions, attentional resources can no longer be recruited to compensate for diminished striatal control of complex movement (Kucinski et al., 2017).

Spatial covariance studies of cholinergic receptor studies in PD and parkinsonian dementia have shown evidence of concomitant bidirectional (increased and decreased) regional binding changes in the patients (Colloby et al., 2016). These patterns of regional cerebral bidirectional changes suggest the presence of compensatory changes in some and degenerative or decompensatory changes in other brain regions. Further research is needed 
to determine whether cholinergic changes in brain regions that spatially overlap with key hubs in important large-scale brain networks may result in altered compensatory or decompensatory functions of such networks.

Topographic changes of cerebral cholinergic system changes may have differential effects on different networks including the ability to switch between different networks processing internal versus external stimuli. For example, brainstem-thalamic cholinergic projections may play a role in bottom-up salience functions subserving optimal alerting to new external stimuli (Kim et al., 2017b), whereas the cortical cholinergic system may play an important role in top-down control of maintaining attention despite the presence of distractor stimuli (Kim et al., 2017a). Impaired ability to efficiently switch between different network functional states may result in cognitive and behavioral inflexibility in PD.

Gait and balance impairments in PD result probably from an intricate interplay of multisystem degenerations and neurotransmitter deficiencies (N. I. Bohnen \& Albin, 2011; N. I. Bohnen \& Jahn, 2013). Gait and postural impairments are putatively mild in early PD probably because of adaptive plasticity in remaining intact non-dopaminergic systems. However, once PD advances to the multisystem stage of disease, the initially compensating non-dopaminergic systems cannot adapt further and more severe clinical morbidity becomes manifest. The cholinergic system may be one of these compensating systems as cholinergic losses have been associated with slow gait speed, falls, and freezing of gait (N. I. Bohnen et al., 2014; N. I. Bohnen et al., 2013; N. I. Bohnen et al., 2009). Furthermore, brainstemthalamic cholinergic projections may play an important role in sensory integration during postural control (Muller et al., 2013). Axial motor impairments depend on widely connected brain regions and cannot be exclusively explained by thalamic or cortical changes alone. The AChE PET ligands are not optimized to estimate AChE binding in the basal ganglia and cerebellum, structures that are very important for motor control and balance yet have the highest density in the brain compared to the cortex and thalamus. Future studies using VAChT ligands are needed to investigate the role of striatal and cerebellar cholinergic system changes and mobility impairments in PD.

Preliminary AChE PET studies in LRRK2 PD suggest evidence of increased or hypercholinergic activity that may reflect compensatory or perhaps neuro-inflammatory responses. The cholinergic system is one among other interacting system where effective compensation or failure of it may contribute to the pathogenesis of PD. Proper assessment whether transmitter changes may be compensatory or already failing will require longitudinal assessment of both detailed clinical, inflammatory and cholinergic biomarker assessments. Identifying PD patients in whom inflammatory processes play a major role in their pathophysiology might offer a new therapeutic window at least for a subgroup of patients.

It is clear that changes in the cholinergic system are widespread in the central and peripheral nervous system. The multitude and magnitude of cholinergic pathologies in PD highlights the importance of drugs or neuromodulation approaches targeting the cholinergic system. Molecular cholinergic imaging is a powerful tool to guide cholinergic drug development in PD. First, imaging may identify patients with hypocholinergic function to select for 
cholinergic pharmacotherapy augmentation studies. Second, cholinergic ligand studies may be used for target engagement studies of novel compounds using target displacement techniques (Baldassarri et al., 2018). PET studies combining nicotinic and muscarinic ligands may be vey useful for improved selection of cholinergic compounds to mitigate specific clinical symptoms in PD.

\section{CONCLUSIONS AND FUTURE DIRECTIONS}

The cholinergic system is only one of more pathophysiological players in the cognitive impairment spectrum of PD. Recent studies suggest that the cholinergic system is not a static layer within a more complex multi-layered pathophysiological model of dementia in PD. The cholinergic system is emerging as a dynamic player within large-scale brain networks and more local circuit neurotransmitter circuits. The regional cerebral biodistribution of cholinergic nerve terminals in the brain implies biological functions that extends well beyond cognition. Limbic cholinergic denervation are an important determinant of olfactory changes and the presence of more severe hyposmia may serve as a risk factor for dementia in PD. Reduced brainstem-thalamic cholinergic activity associates with the presence of RBD in PD. Cholinergic system changes have been associated with falls, slow gait speed, freezing of gait, sensory processing during postural control and dyskinesias in PD. Hypocholinergic intestinal activity is now being studied as a biomarker for early and prodromal PD. Emerging evidence of hypercholinergic activity in prodromal (LRRK2) PD may reflect possible compensatory or neuro-inflammatory responses. Molecular imaging of the cholinergic system is poised to guide and evaluate future cholinergic drug development in PD.

\section{ACKNOWLEDGMENT}

The presented research data from the authors' work was supported by grants from the NIH [P01 NS015655, RO1 NS070856, with additional support from P50 NS091856], Department of Veterans Affairs [I01 RX000317] and the Michael J. Fox Foundation.

\section{ABBREVIATIONS}

AChE

AD

CBFB

DLB

LDTC

LRRK2

PD

PDD

PPN acetylcholinesterase

Alzheimer disease

cholinergic basal forebrain

dementia with Lewy bodies

laterodorsal tegmental complex

leucine-rich repeat kinase 2

Parkinson disease

Parkinson disease with dementia

pedunculopontine nucleus 

PET
Positron Emission Tomography
RBD
rapid eye movement behavior disorder
SPECT
Single Photon Computed Emission Tomography
VAChT
Vesicular Acetylcholine Transporter

\section{REFERENCES}

Adams JR, van Netten H, Schulzer M, Mak E, McKenzie J, Strongosky A, Stoessl AJ (2005). PET in LRRK2 mutations: comparison to sporadic Parkinson's disease and evidence for presymptomatic compensation. Brain, 128(Pt 12), 2777-2785. doi: 10.1093/brain/awh607 [PubMed: 16081470]

Aghourian M, Legault-Denis C, Soucy JP, Rosa-Neto P, Gauthier S, Kostikov A, Bedard MA (2017). Quantification of brain cholinergic denervation in Alzheimer's disease using PET imaging with $\left[{ }^{18}\right.$ F]-FEOBV. Mol Psychiatry, 22(11), 1531-1538. doi: 10.1038/mp.2017.183 [PubMed: 28894304]

Ahlskog JE, \& Muenter MD (2001). Frequency of levodopa-related dyskinesias and motor fluctuations as estimated from the cumulative literature. Mov Disord, 16(3), 448-458. [PubMed: 11391738]

Alves G, Larsen JP, Emre M, Wentzel-Larsen T, \& Aarsland D (2006). Changes in motor subtype and risk for incident dementia in Parkinson's disease. Mov Disord, 21(8), 1123-1130. [PubMed: 16637023]

Anlauf M, Schafer MK, Eiden L, \& Weihe E (2003). Chemical coding of the human gastrointestinal nervous system: cholinergic, VIPergic, and catecholaminergic phenotypes. J Comp Neurol, 459(1), 90-111. doi: 10.1002/cne.10599 [PubMed: 12629668]

Annerino DM, Arshad S, Taylor GM, Adler CH, Beach TG, \& Greene JG (2012). Parkinson's disease is not associated with gastrointestinal myenteric ganglion neuron loss. Acta Neuropathol, 124(5), 665-680. doi: 10.1007/s00401-012-1040-2 [PubMed: 22941241]

Arendt T, Bigl V, Arendt A, \& Tennstedt A (1983). Loss of neurons in the nucleus basalis of Meynert in Alzheimer's disease, paralysis agitans and Korsakoff's Disease. Acta Neuropathol (Berl), 61, 101-108. [PubMed: 6637393]

Asahina M, Shinotoh H, Hirayama K, Suhara T, Shishido F, Inoue O, \& Tateno Y (1995). Hypersensitivity of cortical muscarinic receptors in Parkinson's disease demonstrated by PET. Acta Neurol Scand, 91(6), 437-443. [PubMed: 7572037]

Asahina M, Suhara T, Shinotoh H, Inoue O, Suzuki K, \& Hattori T (1998). Brain muscarinic receptors in progressive supranuclear palsy and Parkinson's disease: a positron emission tomographic study. J Neurol Neurosurg Psychiatry, 65(2), 155-163. [PubMed: 9703164]

Ashburn A, Stack E, Ballinger C, Fazakarley L, \& Fitton C (2008). The circumstances of falls among people with Parkinson's disease and the use of Falls Diaries to facilitate reporting. Disabil Rehabil, 30(16), 1205-1212. doi: 10.1080/09638280701828930 [PubMed: 18608387]

Baba T, Kikuchi A, Hirayama K, Nishio Y, Hosokai Y, Kanno S, Takeda A (2012). Severe olfactory dysfunction is a prodromal symptom of dementia associated with Parkinson's disease: a 3 year longitudinal study. Brain, 135(Pt 1), 161-169. doi: awr321 [pii] 10.1093/brain/awr321 [PubMed: 22287381]

Baldassarri SR, Hillmer AT, Anderson JM, Jatlow P, Nabulsi N, Labaree D, Esterlis I (2018). Use of Electronic Cigarettes Leads to Significant Beta2-Nicotinic Acetylcholine Receptor Occupancy: Evidence From a PET Imaging Study. Nicotine Tob Res, 20(4), 425-433. doi: 10.1093/ntr/ntx091 [PubMed: 28460123]

Barrett MJ, Blair JC, Sperling SA, Smolkin ME, \& Druzgal TJ (2018). Baseline symptoms and basal forebrain volume predict future psychosis in early Parkinson disease. Neurology. doi: 10.1212/ WNL.0000000000005421

Bartus RT, Dean RL, 3rd, Beer B, \& Lippa AS (1982). The cholinergic hypothesis of geriatric memory dysfunction. Science, 217(4558), 408-414. [PubMed: 7046051] 
Beach TG, Adler CH, Sue LI, Vedders L, Lue L, White Iii CL, Arizona Parkinson's Disease, Consortium. (2010). Multi-organ distribution of phosphorylated alpha-synuclein histopathology in subjects with Lewy body disorders. Acta Neuropathol, 119(6), 689-702. doi: 10.1007/ s00401-010-0664-3 [PubMed: 20306269]

Bohnen NI, \& Albin RL (2011). The cholinergic system and Parkinson disease. Behav Brain Res, 221(2), 564-573. doi: S0166-4328(10)00016-1 [pii] 10.1016/j.bbr.2009.12.048 [PubMed: 20060022]

Bohnen NI, Albin RL, Muller ML, Petrou M, Kotagal V, Koeppe RA, Frey KA (2015). Frequency of cholinergic and caudate nucleus dopaminergic deficits across the predemented cognitive spectrum of Parkinson disease and evidence of interaction effects. JAMA Neurol, 72(2), 194-200. doi: 10.1001/jamaneurol.2014.2757 [PubMed: 25506674]

Bohnen NI, Frey KA, Studenski S, Kotagal V, Koeppe RA, Constantine GM, Muller ML (2014). Extra-nigral pathological conditions are common in Parkinson's disease with freezing of gait: An in vivo positron emission tomography study. Mov Disord, 29(9), 1118-1124. doi: 10.1002/mds. 25929 [PubMed: 24909584]

Bohnen NI, Frey KA, Studenski S, Kotagal V, Koeppe RA, Scott PJ, Muller ML (2013). Gait speed in Parkinson disease correlates with cholinergic degeneration. Neurology, 81(18), 1611-1616. doi: WNL.0b013e3182a9f558 [pii] 10.1212/WNL.0b013e3182a9f558 [PubMed: 24078735]

Bohnen NI, Grothe MJ, Ray NJ, Muller Mltm, \& Teipel SJ (2018). Recent advances in cholinergic imaging and cognitive decline-Revisiting the cholinergic hypothesis of dementia. Curr Geriatr Rep, 7(1), 1-11. doi: 10.1007/s13670-018-0234-4 [PubMed: 29503795]

Bohnen NI, \& Jahn K (2013). Imaging: What can it tell us about parkinsonian gait? Mov Disord, 28(11), 1492-1500. doi: 10.1002/mds.25534 [PubMed: 24132837]

Bohnen NI, Kaufer DI, Hendrickson R, Constantine GM, Mathis CA, \& Moore RY (2007). Cortical cholinergic denervation is associated with depressive symptoms in Parkinson's disease and parkinsonian dementia. J Neurol Neurosurg Psychiatry, 78(6), 641-643. [PubMed: 17507447]

Bohnen NI, Kaufer DI, Ivanco LS, Lopresti B, Koeppe RA, Davis JG, DeKosky ST (2003). Cortical cholinergic function is more severely affected in parkinsonian dementia than in Alzheimer disease: an in vivo positron emission tomographic study. Arch Neurol, 60(12), 1745-1748. [PubMed: 14676050]

Bohnen NI, \& Muller ML (2013). In vivo neurochemical imaging of olfactory dysfunction in Parkinson's disease. J Neural Transm (Vienna), 120(4), 571-576. doi: 10.1007/s00702-012-0956-y [PubMed: 23263541]

Bohnen NI, Muller ML, Koeppe RA, Studenski SA, Kilbourn MA, Frey KA, \& Albin RL (2009). History of falls in Parkinson disease is associated with reduced cholinergic activity. Neurology, 73(20), 1670-1676. doi: 73/20/1670 [pii] 10.1212/WNL.0b013e3181c1ded6 [PubMed: 19917989]

Bohnen NI, Muller MLTM, Kotagal V, Koeppe RA, Kilbourn MR, Gilman S, Frey KA (2012). Heterogeneity of cholinergic denervation in Parkinson's disease without dementia. Journal of Cerebral Blood Flow and Metabolism, 32(8), 1609-1617. doi: 10.1038/jcbfm.2012.60 [PubMed: 22569194]

Bohnen NI, Muller Mltm, \& Frey KA (2017). Molecular Imaging and Updated Diagnostic Criteria in Lewy Body Dementias. Curr Neurol Neurosci Rep, 17(10), 73. doi: 10.1007/s11910-017-0789-z [PubMed: 28808912]

Bohnen NI, Muller MLTM, Kotagal V, Koeppe RA, Kilbourn MA, Albin RL, \& Frey KA (2010). Olfactory dysfunction, central cholinergic integrity and cognitive impairment in Parkinson disease. Brain, 133, 1747-1754. [PubMed: 20413575]

Braak H, Del Tredici K, Rub U, de Vos RA, Jansen Steur EN, \& Braak E (2003). Staging of brain pathology related to sporadic Parkinson's disease. Neurobiol Aging, 24(2), 197-211. [PubMed: 12498954]

Brockmann K, Apel A, Schulte C, Schneiderhan-Marra N, Pont-Sunyer C, Vilas D, Maetzler W (2016). Inflammatory profile in LRRK2-associated prodromal and clinical PD. J Neuroinflammation, 13(1), 122. doi: 10.1186/s12974-016-0588-5 [PubMed: 27220776] 
Brumberg J, Kusters S, Al-Momani E, Marotta G, Cosgrove KP, van Dyck CH, ..., Isaias IU (2017). Cholinergic activity and levodopa-induced dyskinesia: a multitracer molecular imaging study. Ann Clin Transl Neurol, 4(9), 632-639. doi: 10.1002/acn3.438 [PubMed: 28904985]

Chou KL, Kotagal V, \& Bohnen NI (2016). Neuroimaging and clinical predictors of fatigue in Parkinson disease. Parkinsonism Relat Disord, 23, 45-49. doi: 10.1016/j.parkreldis.2015.11.029 [PubMed: 26683744]

Chung KA, Lobb BM, Nutt JG, \& Horak FB (2010). Effects of a central cholinesterase inhibitor on reducing falls in Parkinson disease. Neurology, 75(14), 1263-1269. doi: WNL.0b013e3181f6128c [pii] 10.1212/WNL.0b013e3181f6128c [PubMed: 20810998]

Colloby SJ, McKeith IG, Burn DJ, Wyper DJ, O’Brien JT, \& Taylor JP (2016). Cholinergic and perfusion brain networks in Parkinson disease dementia. Neurology, 87(2), 178-185. doi: 10.1212/ WNL.0000000000002839 [PubMed: 27306636]

Colloby SJ, Pakrasi S, Firbank MJ, Perry EK, Piggott MA, Owens J, O’Brien JT (2006). In vivo SPECT imaging of muscarinic acetylcholine receptors using $(\mathrm{R}, \mathrm{R})$ 123I-QNB in dementia with Lewy bodies and Parkinson's disease dementia. Neuroimage, 33(2), 423-429. doi: S1053-8119(06)00755-5 [pii] 10.1016/j.neuroimage.2006.07.026 [PubMed: 16959499]

Colloby SJ, Perry EK, Pakrasi S, Pimlott SL, Wyper DJ, McKeith IG, O’Brien JT (2010). Nicotinic ${ }^{123}$ I-5IA-85380 single photon emission computed tomography as a predictor of cognitive progression in Alzheimer's disease and dementia with Lewy bodies. Am J Geriatr Psychiatry, 18(1), 86-90. doi: 10.1097/JGP.0b013e3181b972aa [PubMed: 20094022]

Counts SE, He B, Che S, Ikonomovic MD, DeKosky ST, Ginsberg SD, \& Mufson EJ (2007). Alpha7 nicotinic receptor up-regulation in cholinergic basal forebrain neurons in Alzheimer disease. Arch Neurol, 64(12), 1771-1776. doi: 10.1001/archneur.64.12.1771 [PubMed: 18071042]

D'Souza RD, \& Vijayaraghavan S (2014). Paying attention to smell: cholinergic signaling in the olfactory bulb. Front Synaptic Neurosci, 6, 21. doi: 10.3389/fnsyn.2014.00021 [PubMed: 25309421]

Darreh-Shori T, Vijayaraghavan S, Aeinehband S, Piehl F, Lindblom RP, Nilsson B, Nordberg A (2013). Functional variability in butyrylcholinesterase activity regulates intrathecal cytokine and astroglial biomarker profiles in patients with Alzheimer's disease. Neurobiol Aging, 34(11), 24652481. doi: 10.1016/j.neurobiolaging.2013.04.027 [PubMed: 23759148]

Davies P, \& Maloney AJF. (1976). Selective loss of central cholinergic neurons in Alzheimer's disease. Lancet, II, 1403.

Davis KL, Mohs RC, Marin D, Purohit DP, Perl DP, Lantz M, Haroutunian V (1999). Cholinergic markers in elderly patients with early signs of Alzheimer disease. JAMA, 281, 1401-1406. [PubMed: 10217056]

DeKosky ST, Ikonomovic MD, Styren SD, Beckett L, Wisniewski S, Bennett DA, Mufson EJ (2002). Upregulation of choline acetyltransferase activity in hippocampus and frontal cortex of elderly subjects with mild cognitive impairment. Ann Neurol, 51(2), 145-155. [PubMed: 11835370]

Doty RL (2012). Olfactory dysfunction in Parkinson disease. Nat Rev Neurol, 8(6), 329-339. doi: 10.1038/nrneurol.2012.80 nrneurol.2012.80 [pii] [PubMed: 22584158]

Drachman DA, \& Leavitt J (1974). Human memory and the cholinergic system. A relationship to aging? Arch Neurol, 30, 113-121. [PubMed: 4359364]

Ewers M, Walsh C, Trojanowski JQ, Shaw LM, Petersen RC, Jack CR, Jr., North American Alzheimer's Disease Neuroimaging, Initiative. (2012). Prediction of conversion from mild cognitive impairment to Alzheimer's disease dementia based upon biomarkers and neuropsychological test performance. Neurobiol Aging, 33(7), 1203-1214. doi: 10.1016/ j.neurobiolaging.2010.10.019 [PubMed: 21159408]

Fedorova TD, Seidelin LB, Knudsen K, Schacht AC, Geday J, Pavese N, Borghammer P (2017). Decreased intestinal acetylcholinesterase in early Parkinson disease: An (11)C-donepezil PET study. Neurology, 88(8), 775-781. doi: 10.1212/WNL.0000000000003633 [PubMed: 28100726]

Fibiger HC. (1982). The organization and some projections of cholinergic neurons of the mammalian forebrain. Brain Res Rev, 4, 327-388. 
Fujita M, Ichise M, Zoghbi SS, Liow JS, Ghose S, Vines DC, Innis RB (2006). Widespread decrease of nicotinic acetylcholine receptors in Parkinson's disease. Ann Neurol, 59(1), 174-177. [PubMed: 16374823]

Gagnon JF, Vendette M, Postuma RB, Desjardins C, Massicotte-Marquez J, Panisset M, \& Montplaisir J (2009). Mild cognitive impairment in rapid eye movement sleep behavior disorder and Parkinson's disease. Ann Neurol, 66(1), 39-47. doi: 10.1002/ana.21680 [PubMed: 19670440]

Gazibara T, Kisic-Tepavcevic D, Svetel M, Tomic A, Stankovic I, Kostic VS, \& Pekmezovic T (2016). Indoor and outdoor falls in persons with Parkinson's disease after 1 year follow-up study: differences and consequences. Neurol Sci, 37(4), 597-602. doi: 10.1007/s10072-016-2504-2 [PubMed: 26879312]

Gilman S, Koeppe RA, Nan B, Wang CN, Wang X, Junck L, Bhaumik A (2010). Cerebral cortical and subcortical cholinergic deficits in parkinsonian syndromes. Neurology, 74(18), 1416-1423. doi: 74/18/1416 [pii] 10.1212/WNL.0b013e3181dc1a55 [PubMed: 20439843]

Gjerloff T, Fedorova T, Knudsen K, Munk OL, Nahimi A, Jacobsen S, Borghammer P (2015). Imaging acetylcholinesterase density in peripheral organs in Parkinson's disease with 11C-donepezil PET. Brain, 138(Pt 3), 653-663. doi: 10.1093/brain/awu369 [PubMed: 25539902]

Gjerloff T, Jakobsen S, Nahimi A, Munk OL, Bender D, Alstrup AK, Borghammer P (2014). In vivo imaging of human acetylcholinesterase density in peripheral organs using 11C-donepezil: dosimetry, biodistribution, and kinetic analyses. J Nucl Med, 55(11), 1818-1824. doi: 10.2967/ jnumed.114.143859 [PubMed: 25324520]

Gratwicke J, Jahanshahi M, \& Foltynie T (2015). Parkinson's disease dementia: a neural networks perspective. Brain, 138(Pt 6), 1454-1476. doi: 10.1093/brain/awv104 [PubMed: 25888551]

Halliday G, Hely M, Reid W, \& Morris J (2008). The progression of pathology in longitudinally followed patients with Parkinson's disease. Acta Neuropathol, 115(4), 409-415. doi: 10.1007/ s00401-008-0344-8 [PubMed: 18231798]

Healy DG, Falchi M, O'Sullivan SS, Bonifati V, Durr A, Bressman S, International, Lrrk Consortium. (2008). Phenotype, genotype, and worldwide genetic penetrance of LRRK2-associated Parkinson's disease: a case-control study. Lancet Neurol, 7(7), 583-590. doi: 10.1016/S1474-4422(08)70117-0 [PubMed: 18539534]

Heckers S, Geula C, \& Mesulam MM. (1992). Cholinergic innervation of the human thalamus: Dual origin and differential nuclear distribution. J Comp Neurol, 325, 68-82. [PubMed: 1282919]

Henderson EJ, Lord SR, Brodie MA, Gaunt DM, Lawrence AD, Close JC, Ben-Shlomo Y (2016). Rivastigmine for gait stability in patients with Parkinson's disease (ReSPonD): a randomised, double-blind, placebo-controlled, phase 2 trial. Lancet Neurol. doi: 10.1016/ S1474-4422(15)00389-0

Hilker R, Thomas AV, Klein JC, Weisenbach S, Kalbe E, Burghaus L, Heiss WD (2005). Dementia in Parkinson disease: functional imaging of cholinergic and dopaminergic pathways. Neurology, 65(11), 1716-1722. [PubMed: 16344512]

Hiraoka K, Okamura N, Funaki Y, Hayashi A, Tashiro M, Hisanaga K, Mori E (2012). Cholinergic deficit and response to donepezil therapy in Parkinson's disease with dementia. Eur Neurol, 68(3), 137-143. doi: 10.1159/000338774 [PubMed: 22832236]

Horti AG, Gao Y, Kuwabara H, Wang Y, Abazyan S, Yasuda RP, Dannals RF (2014). 18F-ASEM, a radiolabeled antagonist for imaging the alpha7-nicotinic acetylcholine receptor with PET. J Nucl Med, 55(4), 672-677. doi: 10.2967/jnumed.113.132068 [PubMed: 24556591]

Ikonomovic MD, Abrahamson EE, Isanski BA, Wuu J, Mufson EJ, \& DeKosky ST (2007). Superior frontal cortex cholinergic axon density in mild cognitive impairment and early Alzheimer disease. Arch Neurol, 64(9), 1312-1317. doi: 10.1001/archneur.64.9.1312 [PubMed: 17846271]

Irie T, Fukushi K, Akimoto Y, Tamagami H, \& Nozaki T (1994). Design and evaluation of radioactive acetylcholine analogs for mapping brain acetylcholinesterase (AChE) in vivo. Nucl Med Biol, 21(801-808).

Irie T, Fukushi K, Namba H, Iyo M, Tamagami H, Nagatsuka S, \& Ikota N (1996). Brain acetylcholinesterase activity: Validation of a PET tracer in a rat model of Alzheimer's disease. $\mathrm{J}$ Nucl Med, 37, 649-655. [PubMed: 8691261] 
Isaias IU, Spiegel J, Brumberg J, Cosgrove KP, Marotta G, Oishi N, Samnick S (2014). Nicotinic acetylcholine receptor density in cognitively intact subjects at an early stage of Parkinson's disease. Front Aging Neurosci, 6, 213. doi: 10.3389/fnagi.2014.00213 [PubMed: 25177294]

Ishikawa K, Motoi Y, Mizuno Y, Kubo S, \& Hattori N (2014). Effects of donepezil dose escalation in Parkinson's patients with dementia receiving long-term donepezil treatment: an exploratory study. Psychogeriatrics, 14(2), 93-100. doi: 10.1111/psyg.12045 [PubMed: 24661498]

Iyo M, Namba H, Fukushi K, Shinotoh H, Nagatsuka S, Suhara T, Irie T (1997). Measurement of acetylcholinesterase by positron emission tomography in the brain of healthy controls and patients with Alzheimer's disease. Lancet, 349, 1805-1809. [PubMed: 9269216]

Kalia LV (2017). Biomarkers for cognitive dysfunction in Parkinson's disease. Parkinsonism Relat Disord. doi: 10.1016/j.parkreldis.2017.07.023

Kalia LV, Lang AE, Hazrati LN, Fujioka S, Wszolek ZK, Dickson DW, Marras C (2015). Clinical correlations with Lewy body pathology in LRRK2-related Parkinson disease. JAMA Neurol, 72(1), 100-105. doi: 10.1001/jamaneurol.2014.2704 [PubMed: 25401511]

Karachi C, Grabli D, Bernard FA, Tande D, Wattiez N, Belaid H, Francois C (2010). Cholinergic mesencephalic neurons are involved in gait and postural disorders in Parkinson disease. J Clin Invest, 120(8), 2745-2754. doi: 10.1172/JCI42642 42642 [pii] [PubMed: 20628197]

Kas A, Bottlaender M, Gallezot JD, Vidailhet M, Villafane G, Gregoire MC, Remy P (2009). Decrease of nicotinic receptors in the nigrostriatal system in Parkinson's disease. J Cereb Blood Flow Metab, 29(9), 1601-1608. doi: jcbfm200974 [pii] 10.1038/jcbfm.2009.74 [PubMed: 19491921]

Kawashima K, Fujii T, Moriwaki Y, \& Misawa H (2012). Critical roles of acetylcholine and the muscarinic and nicotinic acetylcholine receptors in the regulation of immune function. Life Sci, 91(21-22), 1027-1032. doi: 10.1016/j.lfs.2012.05.006 [PubMed: 22659391]

Kehagia AA, Barker RA, \& Robbins TW (2010). Neuropsychological and clinical heterogeneity of cognitive impairment and dementia in patients with Parkinson's disease. Lancet Neurol, 9(12), 1200-1213. doi: S1474-4422(10)70212-X [pii] 10.1016/S 1474-4422(10)70212-X [PubMed: 20880750]

Kilbourn MR, Snyder SE, Sherman PS, \& Kuhl DE. (1996). In vivo studies of acetylcholinesterase activity using a labeled substrate, $\mathrm{N}-\left[{ }^{11} \mathrm{C}\right]$ methylpiperdinyl-4-propionate $\left(\left[{ }^{11} \mathrm{C}\right] \mathrm{PMP}\right)$. Synapse, 22, 123-131. [PubMed: 8787128]

Kim K, Bohnen NI, Muller Mltm, \& Lustig C (2018). Compensatory dopaminergic-cholinergic interactions in conflict processing: Evidence from patients with Parkinson's disease. Neuroimage. doi: 10.1016/j.neuroimage.2018.01.021

Kim K, Muller Mltm, Bohnen NI, Sarter M, \& Lustig C (2017a). The cortical cholinergic system contributes to the top-down control of distraction: Evidence from patients with Parkinson's disease. Neuroimage. doi: 10.1016/j.neuroimage.2017.12.012

Kim K, Muller Mltm, Bohnen NI, Sarter M, \& Lustig C (2017b). Thalamic cholinergic innervation makes a specific bottom-up contribution to signal detection: Evidence from Parkinson's disease patients with defined cholinergic losses. Neuroimage, 149, 295-304. doi: 10.1016/j.neuroimage. 2017.02.006 [PubMed: 28167350]

Klein JC, Eggers C, Kalbe E, Weisenbach S, Hohmann C, Vollmar S, Hilker R (2010). Neurotransmitter changes in dementia with Lewy bodies and Parkinson disease dementia in vivo. Neurology, 74(11), 885-892. doi: 10.1212/WNL.0b013e3181d55f61 WNL.0b013e3181d55f61 [pii] [PubMed: 20181924]

Koeppe RA, Frey KA, Snyder SE, Meyer P, Kilbourn MR, \& Kuhl DE (1999). Kinetic modeling of N$\left[{ }^{11} \mathrm{C}\right]$ methylpiperidin-4-yl propionate: alternatives for analysis of an irreversible positron emission tomography tracer for measurement of acetylcholinesterase activity in human brain. J Cereb Blood Flow Metab, 19, 1150-1163. [PubMed: 10532640]

Kotagal V, Albin RL, Muller MLTM, Koeppe RA, Chervin RD, Frey KA, \& Bohnen NI (2012). Symptoms of Rapid Eye Movement Sleep Behavior Disorder are associated with Cholinergic Denervation in Parkinson Disease. Ann Neurol, 71(4), 560-568. [PubMed: 22522445]

Kotagal V, Muller ML, Kaufer DI, Koeppe RA, \& Bohnen NI (2012). Thalamic cholinergic innervation is spared in Alzheimer disease compared to parkinsonian disorders. Neurosci Lett, 
514(2), 169-172. doi: 10.1016/j.neulet.2012.02.083 S0304-3940(12)00309-6 [pii] [PubMed: 22414859]

Kotzbauer PT, Cairns NJ, Campbell MC, Willis AW, Racette BA, Tabbal SD, \& Perlmutter JS (2012). Pathologic Accumulation of alpha-Synuclein and Abeta in Parkinson Disease Patients With Dementia. Arch Neurol, 69(10), 1-6. doi: 10.1001/archneurol.2012.1608 1217318 [pii]

Kucinski A, de Jong IE, \& Sarter M (2017). Reducing falls in Parkinson's disease: interactions between donepezil and the 5-HT6 receptor antagonist idalopirdine on falls in a rat model of impaired cognitive control of complex movements. Eur J Neurosci, 45(2), 217-231. doi: 10.1111/ ejn.13354 [PubMed: 27469080]

Kucinski A, Paolone G, Bradshaw M, Albin RL, \& Sarter M (2013). Modeling fall propensity in Parkinson's disease: deficits in the attentional control of complex movements in rats with corticalcholinergic and striatal-dopaminergic deafferentation. J Neurosci, 33(42), 16522-16539. doi: 10.1523/JNEUROSCI.2545-13.2013 33/42/16522 [pii] [PubMed: 24133257]

Kuhl DE, Koeppe RA, Fessler JA, Minoshima S, Ackermann RJ, Carey JE, Wieland DM (1994). In vivo mapping of cholinergic neurons in the human brain using SPECT and IBVM. JNucl Med, 35(3), 405-410. [PubMed: 8113884]

Kuhl DE, Koeppe RA, Minoshima S, Snyder SE, Ficaro EP, Foster NL, Kilbourn MR (1999). In vivo mapping of cerebral acetylcholinesterase activity in aging and Alzheimer's disease. Neurology, 52, 691-699. [PubMed: 10078712]

Kuhl DE, Minoshima S, Fessler JA, Frey KA, Foster NL, Ficaro EP, Koeppe RA. (1996). In vivo mapping of cholinergic terminals in normal aging, Alzheimer's disease, and Parkinson's disease. Ann Neurol, 40, 399-410. [PubMed: 8797529]

Levy G (2007). The relationship of Parkinson disease with aging. Arch Neurol, 64(9), 1242-1246. doi: 64/9/1242 [pii] 10.1001/archneur.64.9.1242 [PubMed: 17846263]

Liu S-Y, Wile DJ, Fu J , Valerio J, Shahinfard E, McCormick S, ... Stoessl AJ (2018). The influence of LRRK2 mutations on the cholinergic system in manifest and prodromal stages of Parkinson's disease: a cross-sectional PET study. Lancet Neurol.

Lord S, Rochester L, Hetherington V, Allcock LM, \& Burn D (2010). Executive dysfunction and attention contribute to gait interference in 'off' state Parkinson's Disease. Gait Posture, 31(2), 169-174. doi: S0966-6362(09)00633-X [pii] 10.1016/j.gaitpost.2009.09.019 [PubMed: 19896382]

Luo CY, Guo XY, Song W, Chen Q, Cao B, Yang J, Shang HF (2015). Functional connectome assessed using graph theory in drug-naive Parkinson's disease. J Neurol, 262(6), 1557-1567. doi: 10.1007/ s00415-015-7750-3 [PubMed: 25929663]

Marcone A, Garibotto V, Moresco RM, Florea I, Panzacchi A, Carpinelli A, Perani D (2012). [11C]MP4A PET cholinergic measurements in amnestic mild cognitive impairment, probable Alzheimer's disease, and dementia with Lewy bodies: a Bayesian method and voxel-based analysis. J Alzheimers Dis, 31(2), 387-399. doi: 10.3233/JAD-2012-111748 [PubMed: 22596267]

Marion MH, Qurashi M, Marshall G, \& Foster O (2008). Is REM sleep behaviour disorder (RBD) a risk factor of dementia in idiopathic Parkinson's disease? J Neurol, 255(2), 192-196. doi: 10.1007/ s00415-008-0629-9 [PubMed: 18217187]

Mazere J, Lamare F, Allard M, Fernandez P, \& Mayo W (2017). ${ }^{123}$ I-Iodobenzovesamicol SPECT Imaging of Cholinergic Systems in Dementia with Lewy Bodies. J Nucl Med, 58(1), 123-128. doi: 10.2967/jnumed.116.176180 [PubMed: 27469360]

McKeith IG, Boeve BF, Dickson DW, Halliday G, Taylor JP, Weintraub D, Kosaka K (2017). Diagnosis and management of dementia with Lewy bodies: Fourth consensus report of the DLB Consortium. Neurology, 89(1), 88-100. doi: 10.1212/WNL.0000000000004058 [PubMed: 28592453]

Mesulam MM (1996). The systems-level organization of cholinergic innervation in the human cerebral cortex and its alterations in Alzheimer's disease. Prog Brain Res, 109, 285-297. [PubMed: 9009717]

Mesulam MM, Mufson EJ, Wainer BH, \& Levy AI (1983). Central cholinergic pathways in the rat: An overview based on an alternative nomenclature (CH1-CH-6). Neurosci, 10, 1185-1201. 
Mesulam MM, Mash D, Hersh L, Bothwell M, \& Geula C (1992). Cholinergic innervation of the human striatum, globus pallidus, subthalamic nucleus, substantia nigra, and red nucleus. J Comp Neurol, 323, 252-268. [PubMed: 1401259]

Mesulam MM, Mufson EJ, Levy AI, \& Wainer BH. (1983). Cholinergic innervation of cortex by the basal forebrain: Cytochemistry and cortical connections of the septal area, diagonal band nuclei, nucleus basalis (substantia innominata), and hypothalamus in the rhesus monkey. J Comp Neurol, 214, 170-197. [PubMed: 6841683]

Meyer PM, Strecker K, Kendziorra K, Becker G, Hesse S, Woelpl D, Schwarz J (2009). Reduced alpha4beta $2 *$-nicotinic acetylcholine receptor binding and its relationship to mild cognitive and depressive symptoms in Parkinson disease. Arch Gen Psychiatry, 66(8), 866-877. doi: 66/8/866 [pii] 10.1001/archgenpsychiatry.2009.106 [PubMed: 19652126]

Mulholland GK, Wieland DM, Kilbourn MR, Frey KA, Sherman PS, Carey JE, \& Kuhl DE (1998). $\left[{ }^{18} \mathrm{~F}\right]$ fluoroethoxy-benzovesamicol, a PET radiotracer for the vesicular acetylcholine transporter and cholinergic synapses. Synapse, 30(3), 263-274. [PubMed: 9776130]

Muller ML, Albin RL, Kotagal V, Koeppe RA, Scott PJ, Frey KA, \& Bohnen NI (2013). Thalamic cholinergic innervation and postural sensory integration function in Parkinson's disease. Brain, 136(Pt 11), 3282-3289. doi: 10.1093/brain/awt247 awt247 [pii] [PubMed: 24056537]

Muller ML, \& Bohnen NI (2013). Cholinergic dysfunction in Parkinson's disease. Curr Neurol Neurosci Rep, 13(9), 377. doi: 10.1007/s11910-013-0377-9 [PubMed: 23943367]

Nagatsuka S, Fukushi K, Shinotoh H, Namba H, Iyo M, Tanaka N, Irie T (2001). Kinetic analysis of $\left[\left({ }^{11}\right)\right.$ C $]$ MP4A using a high-radioactivity brain region that represents an integrated input function for measurement of cerebral acetylcholinesterase activity without arterial blood sampling. $\mathrm{J}$ Cereb Blood Flow Metab, 21(11), 1354-1366. [PubMed: 11702050]

Nieuwboer A, \& Giladi N (2013). Characterizing freezing of gait in Parkinson's disease: models of an episodic phenomenon. Mov Disord, 28(11), 1509-1519. doi: 10.1002/mds.25683 [PubMed: 24132839]

O’Brien JT, Colloby SJ, Pakrasi S, Perry EK, Pimlott SL, Wyper DJ, Williams ED (2008). Nicotinic alpha4beta2 receptor binding in dementia with Lewy bodies using 123I-5IA-85380 SPECT demonstrates a link between occipital changes and visual hallucinations. Neuroimage, 40(3), 1056-1063. doi: S1053-8119(08)00026-8 [pii] 10.1016/j.neuroimage.2008.01.010 [PubMed: 18295510]

Oishi N, Hashikawa K, Yoshida H, Ishizu K, Ueda M, Kawashima H, Fukuyama H (2007). Quantification of nicotinic acetylcholine receptors in Parkinson's disease with (123)I-5IA SPECT. J Neurol Sci, 256(1-2), 52-60. doi: S0022-510X(07)00136-0 [pii] 10.1016/j.jns. 2007.02.014 [PubMed: 17367812]

Pagano G, Yousaf T, \& Politis M (2017). PET Molecular Imaging Research of Levodopa-Induced Dyskinesias in Parkinson's Disease. Curr Neurol Neurosci Rep, 17(11), 90. doi: 10.1007/ s11910-017-0794-2 [PubMed: 28975571]

Perez-Lloret S, \& Barrantes FJ (2016). Deficits in cholinergic neurotransmission and their clinical correlates in Parkinson's disease. npj Parkinson's disease, 2, 16001. doi: doi: 10.1038/npjparkd. 2016.1

Perry EK, Perry RH, Blessed G, \& Tomlinson BE (1977). Necropsy evidence of central cholinergic deficits in senile dementia. Lancet(I), 189.

Petrou M, Frey KA, Kilbourn MR, Scott PJ, Raffel DM, Bohnen NI, Koeppe RA (2014). In vivo imaging of human cholinergic nerve terminals with (-)-5-(18)F-fluoroethoxybenzovesamicol: biodistribution, dosimetry, and tracer kinetic analyses. J Nucl Med, 55(3), 396-404. doi: 10.2967/ jnumed.113.124792 [PubMed: 24481024]

Quik M, Bordia T, Zhang D, \& Perez XA (2015). Nicotine and Nicotinic Receptor Drugs: Potential for Parkinson's Disease and Drug-Induced Movement Disorders. Int Rev Neurobiol, 124, 247-271. doi: 10.1016/bs.irn.2015.07.005 [PubMed: 26472532]

Remy P, Doder M, Lees A, Turjanski N, \& Brooks D (2005). Depression in Parkinson's disease: loss of dopamine and noradrenaline innervation in the limbic system. Brain, 128, 1314-1322. [PubMed: 15716302] 
Rudzinska M, Bukowczan S, Stozek J, Zajdel K, Mirek E, Chwala W, Szczudlik A (2013). Causes and consequences of falls in Parkinson disease patients in a prospective study. Neurol Neurochir Pol, 47(5), 423-430. [PubMed: 24166563]

Sabri O, Meyer PM, Graf S, Hesse S, Wilke S, Becker GA, Brust P (2018). Cognitive correlates of alpha4beta2 nicotinic acetylcholine receptors in mild Alzheimer's dementia. Brain. doi: 10.1093/ brain/awy099

Saji H, Ogawa M, Ueda M, Iida Y, Magata Y, Tominaga A, Mukai T (2002). Evaluation of radioiodinated 5-iodo-3-(2(S)-azetidinylmethoxy)pyridine as a ligand for SPECT investigations of brain nicotinic acetylcholine receptors. Ann Nucl Med, 16(3), 189-200. [PubMed: 12126044]

Sarter M, Albin RL, Kucinski A, \& Lustig C (2014). Where attention falls: Increased risk of falls from the converging impact of cortical cholinergic and midbrain dopamine loss on striatal function. Exp Neurol, 257C, 120-129. doi: 10.1016/j.expneurol.2014.04.032

Shah N, Frey KA, Muller MLTM, Petrou M, Kotagal V, Koeppe RA, Bohnen NI (2016). Striatal and Cortical beta-Amyloidopathy and Cognition in Parkinson's Disease. Mov Disord, 31(1), 111117. doi: 10.1002/mds.26369 [PubMed: 26380951]

Shimada H, Hirano S, Shinotoh H, Aotsuka A, Sato K, Tanaka N, Irie T (2009). Mapping of brain acetylcholinesterase alterations in Lewy body disease by PET. Neurology, 73(4), 273-278. [PubMed: 19474411]

Shimada H, Hirano S, Sinotoh H, Ota T, Tanaka N, Sato K, Suhara T (2015). Dementia with Lewy bodies can be well-differentiated from Alzheimer's disease by measurement of brain acetylcholinesterase activity-a [11C]MP4A PET study. Int J Geriatr Psychiatry, 30(11), 11051113. doi: 10.1002/gps.4338 [PubMed: 26280153]

Shinotoh H, Asahina M, Inoue O, Suhara T, Hirayama K, \& Tateno Y (1994). Effects of trihexyphenidyl and L-dopa on brain muscarinic cholinergic receptor binding measured by positron emission tomography. J Neural Transm Park Dis Dement Sect, 7(1), 35-46. [PubMed: 8579768]

Shinotoh H, Namba H, Yamaguchi M, Fukushi K, Nagatsuka S, Iyo M, Irie T (1999). Positron emission tomographic measurement of acetylcholinesterase activity reveals differential loss of ascending cholinergic systems in Parkinson's disease and progressive supranuclear palsy. Ann Neurol, 46, 62-69. [PubMed: 10401781]

Shute CC, \& Lewis PR (1966). Electron microscopy of cholinergic terminals and acetylcholinesterasecontaining neurones in the hippocampal formation of the rat. Z Zellforsch Mikrosk Anat, 69, 334-343. [PubMed: 5973099]

Smits R, Fischer S, Hiller A, Deuther-Conrad W, Wenzel B, Patt M, Hoepping A (2014). Synthesis and biological evaluation of both enantiomers of [(18)F]flubatine, promising radiotracers with fast kinetics for the imaging of alpha4beta2-nicotinic acetylcholine receptors. Bioorg Med Chem, 22(2), 804-812. doi: 10.1016/j.bmc.2013.12.011 [PubMed: 24369841]

Snyder SE, Tluczek L, Jewett DM, Nguyen TB, Kuhl DE, \& Kilbourn MR (1998). Synthesis of 1$\left[{ }^{11} \mathrm{C}\right]$ methylpiperidin-4-yl propionate $\left(\left[{ }^{11} \mathrm{C}\right] \mathrm{PMP}\right)$ for in vivo measurements of acetylcholinesterase activity. Nucl Med Biol, 25, 751-754. [PubMed: 9863562]

Weathers SP, Kotagal V, Bohnen NI, \& Chou KL (2014). Risky driving and pedunculopontine nucleusthalamic cholinergic denervation in Parkinson disease. Parkinsonism Relat Disord, 20(1), 13-16. doi: 10.1016/j.parkreldis.2013.08.021 [PubMed: 24070538]

Weintraub D, Morales KH, Moberg PJ, Bilker WB, Balderston C, Duda JE, Stern MB (2005). Antidepressant studies in Parkinson's disease: a review and meta-analysis. Mov Disord, 20(9), 1161-1169. [PubMed: 15954137]

Whitehouse PJ, Hedreen JC, White CL, \& Price DL (1983). Basal forebrain neurons in the dementia of Parkinson disease. Ann Neurol, 13, 243-248. [PubMed: 6847136]

Williams-Gray CH, Mason L, Evans JR, Foltynie T, Brayne C, Robbins TW, \& Barker RA (2013). The CamPaIGN study of Parkinson's disease: 10-year outlook in an incident population-based cohort. J Neurol Neurosurg Psychiatry, 84(11), 1258-1264. doi: 10.1136/jnnp-2013-305277 jnnp-2013-305277 [pii] [PubMed: 23781007] 
Wong KK, Raffel DM, Koeppe RA, Frey KA, Bohnen NI, \& Gilman S (2012). Pattern of cardiac sympathetic denervation in idiopathic Parkinson disease studied with $11 \mathrm{C}$ hydroxyephedrine PET. Radiology, 265(1), 240-247. doi: 10.1148/radiol.12112723 [PubMed: 22843766]

Woolf NJ (1991). Cholinergic systems in mammalian brain and spinal cord. Prog Neurobiol, 37(6), 475-524. [PubMed: 1763188]

Wright CI, Geula C, \& Mesulam MM (1993). Neurological cholinesterases in the normal brain and in Alzheimer's disease: relationship to plaques, tangles, and patterns of selective vulnerability. Ann Neurol, 34(3), 373-384. [PubMed: 8363355]

Yarnall A, Rochester L, \& Burn DJ (2011). The interplay of cholinergic function, attention, and falls in Parkinson's disease. Mov Disord, 26(14), 2496-2503. doi: 10.1002/mds.23932 [PubMed: 21898597]

Yeo BT, Krienen FM, Sepulcre J, Sabuncu MR, Lashkari D, Hollinshead M, ... Buckner RL (2011). The organization of the human cerebral cortex estimated by intrinsic functional connectivity. J Neurophysiol, 106(3), 1125-1165. doi: 10.1152/jn.00338.2011 [PubMed: 21653723]

Yogev G, Giladi N, Peretz C, Springer S, Simon ES, \& Hausdorff JM (2005). Dual tasking, gait rhythmicity, and Parkinson's disease: which aspects of gait are attention demanding? Eur JNeurosci, 22(5), 1248-1256. doi: EJN4298 [pii] 10.1111/j.1460-9568.2005.04298.x [PubMed: 16176368]

Zemek F, Drtinova L, Nepovimova E, Sepsova V, Korabecny J, Klimes J, \& Kuca K (2014). Outcomes of Alzheimer's disease therapy with acetylcholinesterase inhibitors and memantine. Expert Opin Drug Saf, 13(6), 759-774. doi: 10.1517/14740338.2014.914168 [PubMed: 24845946] 


\section{Cholinergic Synapse Radioligand Imaging Targets}

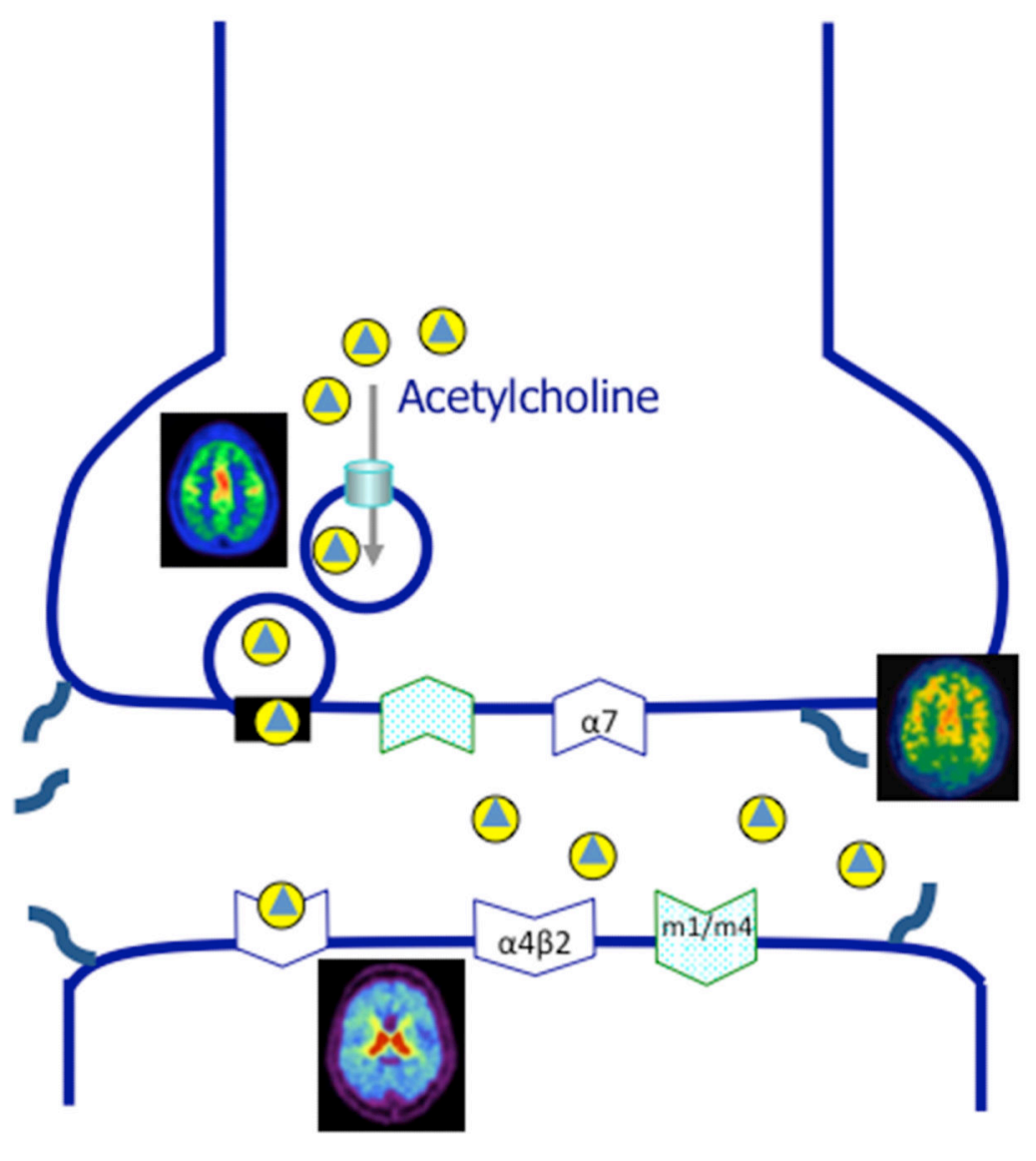

VAChT:

(1] $\left[{ }^{123} \mathrm{I}\right]-\mathrm{IBVM}$

$\left[{ }^{18} \mathrm{~F}\right]-\mathrm{FEOBV}$

\section{AChE:}

$\left[{ }^{11} \mathrm{C}\right]-\mathrm{PMP}$

$\left[{ }^{11} \mathrm{C}\right]-\mathrm{MP} 4 \mathrm{~A}$

$\left[{ }^{11} \mathrm{C}\right]$-donepezil

Nicotinic

Receptors:

[11C]-nicotine

a $4 \beta 2$ :

5-[123I]-5IA-85380

2-[18F]-FA-85380

$\left[{ }^{18} \mathrm{~F}\right]$-Flubatine

a7:

[ $\left.{ }^{18} \mathrm{~F}\right]$-ASEM

Muscarinic Receptors:

$\left[{ }^{11} \mathrm{C}\right]-N M P B$

Figure 1.

ACh nerve terminal figure illustrating pre-synaptic and post-synaptic molecular cholinergic imaging targets. 


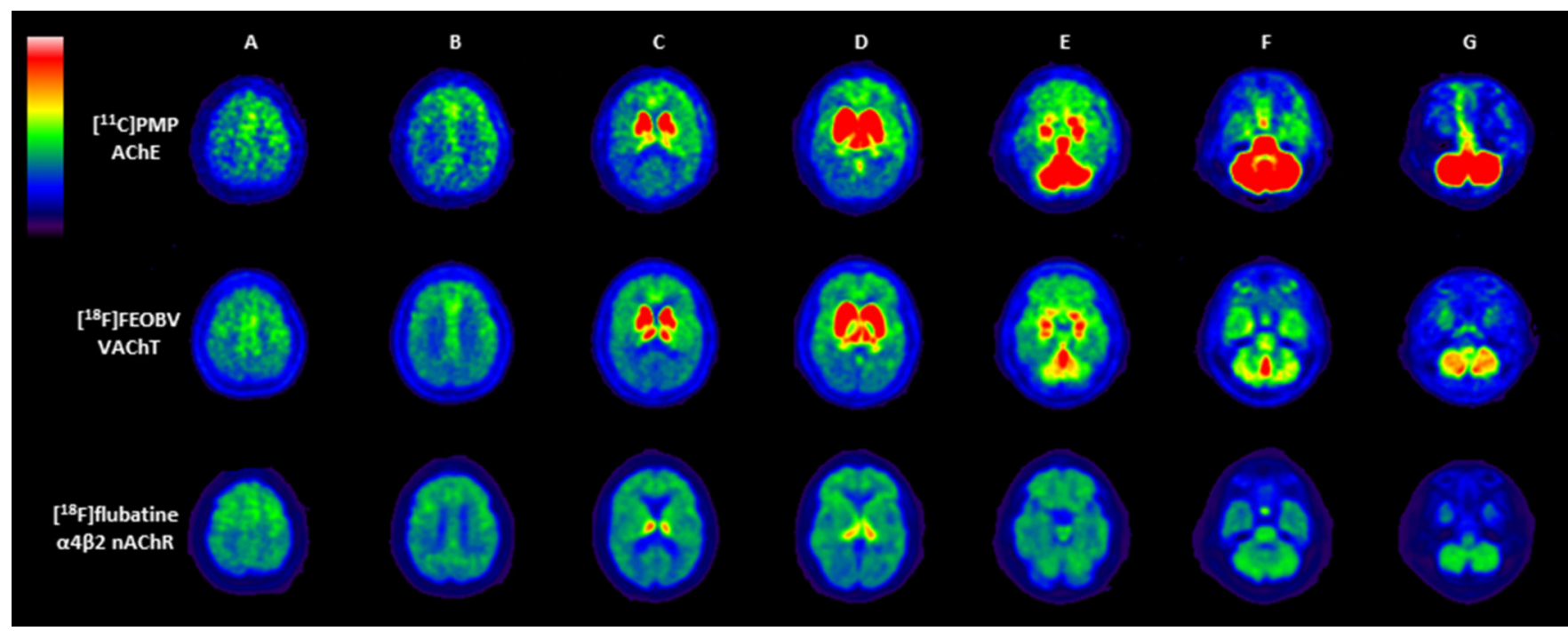

Figure 2.

Multiligand cholinergic PET study in a single PD subject using $\left[{ }^{11} \mathrm{C}\right]-\mathrm{PMP}$ AChE (top row), $\left[{ }^{18} \mathrm{~F}\right]$-FEOBV VAChT (middle row), and $\left[{ }^{18} \mathrm{~F}\right]$-Flubatine $a 4 \beta 2 \mathrm{nAChR}$ (bottom row) PET. Columns A-B: all three tracers show uptake in the cortex, with relatively more increased uptake in the anterior frontotemporal cortices. Columns C-D: both $\left[{ }^{11} \mathrm{C}\right]-\mathrm{PMP}$ and $\left[{ }^{18} \mathrm{~F}\right]-$ FEOBV show intense uptake in the striatum and thalamus. $\left[{ }^{18} \mathrm{~F}\right]$-Flubatine shows intense uptake in the thalamus but only limited uptake in the striatum. Columns E-G: $\left[{ }^{18} \mathrm{~F}\right]-\mathrm{FEOBV}$ shows intense uptake in the cerebellar vermis especially while $\left[{ }^{11} \mathrm{C}\right]-\mathrm{PMP}$ has intense uptake in the entire cerebellum. $\left[{ }^{18} \mathrm{~F}\right]$-Flubatine shows lower and more diffuse uptake in the cerebellum. All three tracers show uptake in the pontine region, with $\left[{ }^{11} \mathrm{C}\right]-\mathrm{PMP}>\left[{ }^{18} \mathrm{~F}\right]-$ FEOBV $>\left[{ }^{18} \mathrm{~F}\right]$-Flubatine. 


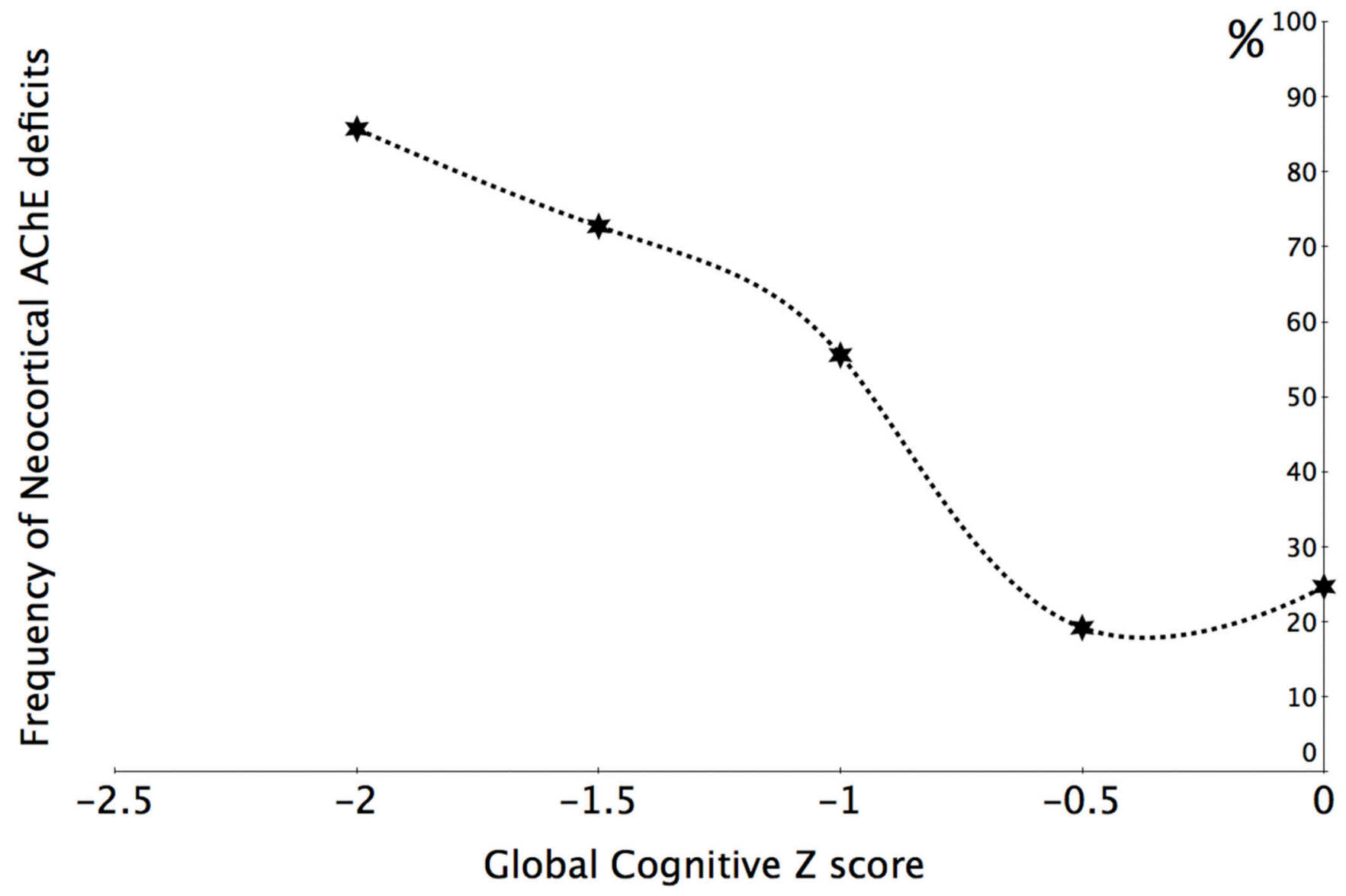

Figure 3.

Cortical cholinergic denervation is a major neurodegeneration associated with progressive declines across the spectrum of cognitive impairment in PD. The relative frequencies of significant neocortical hypocholinergic activity increases from about $25 \%$ in patients with no or minimal cognitive impairment to over $85 \%$ in patients with a global cognitive Z-score of 2 standard deviations below the normal range of cognitive performance (N. I. Bohnen et al., 2015) 
Table 1.

Cholinergic cell groups and their projection areas (from (M. M. Mesulam, 1996)) that are target areas for cholinergic molecular imaging. Increasing camera resolution will increasingly allow assessment of small cholinergic cell groups, such as Ch4, Ch5 and 6.

\begin{tabular}{|l|l|}
\hline Cholinergic cell group & Major projection area \\
\hline Ch1: medial septal nucleus & Hippocampus \\
\hline Ch2: vertical limb nucleus of the diagonal band of Broca & Hippocampus \\
\hline Ch3: horizontal limb nucleus of the diagonal band of Broca & Olfactory bulb \\
\hline Ch4: nucleus basalis of Meynert & Amygdala \& neocortex \\
\hline Ch5: pedunculopontine nucleus & Thalamus \\
\hline Ch6: laterodorsal tegmental complex & Thalamus \\
\hline
\end{tabular}


Table 2.

Summary of AChE activity brain PET studies in PD and parkinsonian dementia.

\begin{tabular}{|c|c|c|c|}
\hline Reference & AChE ligand & Population & Main findings and clinical correlates \\
\hline $\begin{array}{l}\text { (N. I. Bohnen et al., } \\
\text { 2003) }\end{array}$ & {$\left[{ }^{11} \mathrm{C}\right]-\mathrm{PMP} \mathrm{AChE}$} & PD, PDD, DLB & $\begin{array}{l}\text { Mean cortical reductions of } 12.9 \% \text { in PD, } 19.8 \% \text { in PDD and } 20.2 \% \text { in } \\
\text { DLB patients compared to normal control subjects. }\end{array}$ \\
\hline $\begin{array}{l}\text { (Shinotoh et al., } \\
\text { 1999) }\end{array}$ & {$\left[{ }^{11} \mathrm{C}\right]-\mathrm{MP} 4 \mathrm{~A} \mathrm{AChE}$} & $\mathrm{PD} / \mathrm{PDD}$ & $\begin{array}{l}\text { Significant cortical reduction of } 17.0 \% \text { and non-significant thalamic } \\
\text { reduction of } 13 \% \text { in PD patients compared to normal control subjects. }\end{array}$ \\
\hline (Hilker et al., 2005) & {$\left[{ }^{11} \mathrm{C}\right]-\mathrm{MP} 4 \mathrm{~A} \mathrm{AChE}$} & PD, PDD & $\begin{array}{l}\text { Global cortical MP4A binding was severely reduced in PDD ( } 29.7 \%) \text { and } \\
\text { moderately decreased in PD (10.7\%) compared to controls. Voxel-based } \\
\text { analysis showed that patients with PDD had significantly lower MP4A } \\
\text { binding in the left inferior parietal lobule, the left precentral gyrus, and in } \\
\text { the right posterior cingulate gyrus in comparison with PD. }\end{array}$ \\
\hline $\begin{array}{l}\text { (N. I. Bohnen et al., } \\
\text { 2009) }\end{array}$ & {$\left[{ }^{11} \mathrm{C}\right]-\mathrm{PMP} \mathrm{AChE}$} & $\mathrm{PD}$ & $\begin{array}{l}\text { Average cortical and thalamic reductions compared to control subjects } \\
\text { were } 10.7 \% \text { and } 6.4 \% \text {, respectively. }\end{array}$ \\
\hline $\begin{array}{l}\text { (Shimada et al., } \\
\text { 2009) }\end{array}$ & {$\left[{ }^{11} \mathrm{C}\right]-\mathrm{MP} 4 \mathrm{~A}$ AChE } & $\mathrm{D}, \mathrm{PDD} / \mathrm{DLB}$ & $\begin{array}{l}\text { Average cortical reductions of } 12 \% \text { in the PD and } 27 \% \text { in the PDD/DLB } \\
\text { patients. }\end{array}$ \\
\hline (Klein et al., 2010) & {$\left[{ }^{11} \mathrm{C}\right]-\mathrm{MP} 4 \mathrm{~A} A C h E$} & PD, PDD, DLB & $\begin{array}{l}\text { Mean global cortical reductions of } 22.6 \% \text { in PD, } 33.2 \% \text { in PDD and } 22.2 \% \\
\text { in DLB patients compared to normal control subjects. Occipital cortex } \\
\text { reductions were } 15.6 \% \text { in PD, } 35.6 \% \text { in PDD and } 26.0 \% \text { in DLB patients. } \\
\text { Patients with PDD and DLB showed decreasing signal from frontal to } \\
\text { occipital regions. }\end{array}$ \\
\hline $\begin{array}{l}\text { (Gilman et al., } \\
\text { 2010) }\end{array}$ & {$\left[{ }^{11} \mathrm{C}\right]-\mathrm{PMP} \mathrm{AChE}$} & PD & $\begin{array}{l}\text { Mean cortical reduction of } 15.3 \% \text { compared to normal control subjects. } \\
\text { There were some regional cortical AChE binding reduction differences in } \\
\text { the DLB compared to the normal control subjects: anterior cingulum } \\
(-13.6 \%) \text {, lateral frontal }(-13.3 \%) \text {, superior lateral parietal lobe }(-17.1 \%) \text {, } \\
\text { inferior lateral parietal lobe }(-17.9 \%) \text {, superior lateral temporal }(-21.5 \%) \text {, } \\
\text { inferior lateral temporal }(-15.1 \%) \text {, amygdala }(-17.0 \%) \text { and hippocampus } \\
(-13.9 \%) \text {. Subcortical estimates (using arterial input function): striatum } \\
(-10.5 \%) \text {, cerebellum }(-22.9 \%) \text {, pons }(10.5 \%) \text {, mesencephalon }(-11.5 \%) \\
\text { and thalamus }(-14.7 \%) \text {. }\end{array}$ \\
\hline $\begin{array}{l}\text { (N. I. Bohnen et al., } \\
\text { 2012) }\end{array}$ & {$\left[{ }^{11} \mathrm{C}\right]-\mathrm{PMP} \mathrm{AChE}$} & PD & $\begin{array}{l}\text { Average cortical and thalamic reductions compared to control subjects } \\
\text { were } 10.3 \% \text { and } 9.5 \% \text {, respectively. }\end{array}$ \\
\hline $\begin{array}{l}\text { (Hiraoka et al., } \\
\text { 2012) }\end{array}$ & {$\left[{ }^{11} \mathrm{C}\right]$-donepezil AChE } & PDD & Mean cortical reduction of $22.7 \%$ compared to normal control subjects. \\
\hline $\begin{array}{l}\text { (Shimada et al., } \\
\text { 2015) }\end{array}$ & {$\left[{ }^{11} \mathrm{C}\right]-\mathrm{MP} 4 \mathrm{~A}$ AChE } & DLB & $\begin{array}{l}\text { Mean cortical reduction of } 27.8 \% \text { compared to normal control subjects and } \\
\text { substantially more than patients with AD. There were some regional } \\
\text { cortical AChE binding reduction differences in the DLB patients compared } \\
\text { to the normal control subjects: anterior cingulum }(-14.8 \%) \text {, frontal } \\
(-25.3 \%) \text {, temporal }(-30.9 \%) \text {, parietal lobe }(-31.2 \%) \text { and occipital lobe } \\
(-29.5 \%) \text {, posterior cingulum }(-31.2 \%) \text {. }\end{array}$ \\
\hline $\begin{array}{l}\text { (Kotagal, Muller, } \\
\text { Kaufer, Koeppe, \& } \\
\text { Bohnen, 2012) }\end{array}$ & {$\left[{ }^{11} \mathrm{C}\right]-\mathrm{PMP} \mathrm{AChE}$} & PD, PDD, DLB & $\begin{array}{l}\text { Compared to normal control subjects, reduced thalamic AChE binding was } \\
\text { noted in patients with PD }(-12.8 \%) \text {, PDD }(-19.8 \%) \text {, and DLB }(-17.4 \%) \text {. }\end{array}$ \\
\hline
\end{tabular}


Table 3.

SPECT VAChT studies in PD and parkinsonian dementia

\begin{tabular}{|l|l|l|l|}
\hline Reference & VAChT ligand & Population & Main findings and clinical correlates \\
\hline $\begin{array}{l}\text { (D. Kuhl et al., } \\
\text { 1996). }\end{array}$ & $\left.{ }^{123} \mathrm{I}\right]-\mathrm{IBVM}$ & PD/D & $\begin{array}{l}\text { More severe and extensive VAChT binding losses in PDD compared to PD. In PD } \\
\text { without dementia, binding was reduced only in parietal (-19\%) and occipital cortex } \\
(-21 \%) \text {. Non-significant increases were seen in the anterior cingulum }(+5 \%) \text { and } \\
\text { striatum }(+8 \%) \text { in the PD patients. }\end{array}$ \\
\hline $\begin{array}{l}\text { (Mazere et al., } \\
\text { 2017). }\end{array}$ & {$\left[{ }^{123}\right.$ I]-IBVM } & DLB & $\begin{array}{l}\text { Prominent VAChT cortical and subcortical (thalamus, basal ganglia) losses were } \\
\text { observed in the DLB patients compared to normal control subjects. }\end{array}$ \\
\hline
\end{tabular}


Table 4.

Summary of nAChR SPECT and PET binding studies in PD and parkinsonian dementia.

\begin{tabular}{|c|c|c|c|}
\hline Reference & nAChR ligand & Population & Main findings and clinical correlates \\
\hline (Fujita et al., 2006). & {$\left[{ }^{123} \mathrm{I}\right]-5-\mathrm{IA}-85380$} & $\mathrm{PD}$ & $\begin{array}{l}\text { Widespread cortical and subcortical nAChR binding reductions in the PD } \\
\text { patients compared to control subjects, including the pons, cerebellum, } \\
\text { striatum and thalamus. }\end{array}$ \\
\hline (Oishi et al., 2007) & {$\left[{ }^{123} \mathrm{I}\right]-5-\mathrm{IA}-85380$} & $\mathrm{PD}$ & $\begin{array}{l}\text { Widespread cortical and subcortical nAChR binding reductions in PD patients } \\
\text { compared to control subjects, in particular in the frontal cortex and brainstem. }\end{array}$ \\
\hline (Meyer et al., 2009) & {$\left[{ }^{18} \mathrm{~F}\right]$-Fluoro-A-85380 } & $\mathrm{PD}$ & $\begin{array}{l}\text { Widespread cortical and subcortical losses, including the hippocampus, } \\
\text { amygdala, cerebellum, thalamus, and putamen in PD patients compared to } \\
\text { control subjects. }\end{array}$ \\
\hline (Kas et al., 2009) & {$\left[{ }^{18} \mathrm{I}\right]$-Fluoro-A-85380 } & $\mathrm{PD}$ & $\begin{array}{l}\text { Reduced nAChR binding in the substantia nigra and the striatum in the PD } \\
\text { patients compared to the normal control subjects. }\end{array}$ \\
\hline $\begin{array}{l}\text { (O’Brien et al., } \\
\text { 2008) }\end{array}$ & {$\left[{ }^{123} \mathrm{I}\right]-5-\mathrm{IA}-85380$} & DLB & $\begin{array}{l}\text { Reduced nAChR binding in striatal, left superior temporal, right inferior } \\
\text { frontal and cingulate gyri regions except for relatively increased occipital } \\
\text { (bilateral cuneus) and left precuneus receptor binding. }\end{array}$ \\
\hline $\begin{array}{l}\text { (Colloby et al., } \\
2010)\end{array}$ & {$\left[{ }^{123} \mathrm{I}\right]-5-\mathrm{IA}-85380$} & DLB & $\begin{array}{l}\text { Decreased nAChR binding in left superior, middle, and inferior frontal gyri } \\
\text { and pre-/post-central and anterior cingulate regions significantly correlated } \\
\text { with decline in executive function in a pooled analysis comprising DLB and } \\
\text { AD patients. }\end{array}$ \\
\hline
\end{tabular}


Table 5.

Summary of regional mAChR SPECT and PET binding studies in PD and parkinsonian dementia.

\begin{tabular}{|l|l|l|l|}
\hline Reference & mAChR ligand & Population & Main findings and clinical correlates \\
\hline $\begin{array}{l}\text { (Shinotoh et al., } \\
1994)\end{array}$ & {$\left[{ }^{11} \mathrm{C}\right]-\mathrm{NMPB}$} & $\mathrm{PD}$ & $\begin{array}{l}\text { Administration of trihexyphenidyl (antimuscarinic agent) resulted in 28\% inhibition } \\
\text { of mAChR occupancy in the patients. }\end{array}$ \\
\hline $\begin{array}{l}\text { (Asahina et al., } \\
\text { 1995) }\end{array}$ & {$\left[{ }^{11} \mathrm{C}\right]-\mathrm{NMPB}$} & $\mathrm{PD}$ & $\begin{array}{l}\text { Receptor binding calculated by a graphical method, was } 20 \% \text { higher in the frontal } \\
\text { cortex of PD patients than controls (p < 0.05). Increased expression of mAChRs in } \\
\text { the frontal cortex of PD patients may be a compensatory response to a loss of } \\
\text { ascending cholinergic input to that region, and may reflect frontal lobe dysfunction in } \\
\text { PD. }\end{array}$ \\
\hline $\begin{array}{l}\text { (Asahina et al., } \\
\text { 1998). }\end{array}$ & {$\left[{ }^{11} \mathrm{C}\right]-\mathrm{NMPB}$} & PD/PDD & $\begin{array}{l}\text { Increased mAChR binding in the frontal lobe in PD without dementia that was more } \\
\text { prominent in a patient with PDD. Increases in the striatum and parietotemporal } \\
\text { cortices were not significant. }\end{array}$ \\
\hline $\begin{array}{l}\text { (Colloby et al., } \\
\text { 2006) }\end{array}$ & {$\left[{ }^{123} \mathrm{I}\right]-\mathrm{QNB}$} & DLB, PDD & $\begin{array}{l}\text { Increased mAChR receptor binding in right occipital lobe in DLB and right and left } \\
\text { occipital lobes in PDD patients in a voxel-based analysis compared control subjects. }\end{array}$ \\
\hline
\end{tabular}


Table 6.

Topographic and covariance changes of cholinergic receptor changes in PD and parkinsonian dementia: Implication for large-scale brain networks.

\begin{tabular}{|l|l|l|l|}
\hline Reference & Radioligand & Population & Main findings and clinical correlates \\
\hline $\begin{array}{l}\text { (Colloby et al., } \\
\text { 2016). }\end{array}$ & $\left.{ }^{123} \mathrm{I}\right]-\mathrm{QNB} \mathrm{mAChR}$ & PDD & $\begin{array}{l}\text { Reduced mAChR binding in basal forebrain, temporal, striatal, insula, and } \\
\text { anterior cingulate regions together with concomitant preserved or increased } \\
\text { binding in frontal and parieto-occipital areas. }\end{array}$ \\
\hline (Isaias et al., 2014). & {$\left[\begin{array}{l}123 \mathrm{I}]-5 \mathrm{IA} \text { a } 4 \beta 2 * \text { nAChR } \\
\text { PD }\end{array}\right.$} & $\begin{array}{l}\text { Reduced regional nAChR binding (caudate nucleus, orbitofrontal cortex, } \\
\text { and the middle temporal gyrus) but with higher binding in the putamen, } \\
\text { insular cortex and the supplemental motor area. }\end{array}$ \\
\hline
\end{tabular}

